\title{
What's in a Concept? Conceptualizing the Nonconceptual in Buddhist Philosophy and Cognitive Science
}

Evan Thompson

Forthcoming in Christian Coseru, ed., Reasons and Empty Persons: Mind, Metaphysics, and Morality: Essays in Honor of Mark Siderits. London: Springer, 2021.

$[\mathrm{O}]$ ne and the same philosophical issue can be a matter of contention in philosophical centers entirely distinct from each other, widely separated in time and space, and belonging to disparate cultures. And this in its turn provides a compelling argument for two things: first, for the genuine universality of some major philosophical problems; and, second, for the desirability of further comparative study of the respects in which the two philosophical traditions in question may illustrate this universality... (Strawson 1999: 327)

A recurrent problem in the philosophical debates over whether there is or can be nonconceptual experience or whether all experience is conceptually structured, mediated, or dependent is the lack of a generally accepted account of what concepts are. Without a precise specification of what a concept is, the notion of nonconceptuality is equally ill defined. This problem cuts across contemporary philosophy and cognitive science as well as classical Indian philosophy (Siderits, Tillemans, and Chakrabarti 2011), and it affects how we go about philosophically "engaging Buddhism" (Garfield 2015) in particular. Buddhist philosophers generally argue that our everyday experience of the world is conceptually constructed. For example, they argue that what appear to us to be stable, enduring entities possessing properties and belonging to kinds are fictions created by the imposition of concepts onto the incessant flux of momentary events. At the same time, "nonconceptual cognition" (nirvikalpa jñāna) marks the limits of conceptuality. But what precisely do "conceptual" and "nonconceptual" mean? Consider that "concept" is routinely used to translate the Sanskrit term, vikalpa; nirvikalpa is accordingly rendered as "nonconceptual." But vikalpa has also been rendered as "imagination" (Matilal 1986: 312-315), “discriminative construction" (Urban and Griffiths 1994), "discursive thought” (Wayman 1992), and "discrimination" (Sharf 2018). Related terms, such as kalpanā (conceptualization/mental construction) and kalpanāpoḍa (devoid of conceptualization/mental construction), have also been rendered in various ways. Besides the question of how to translate these terms in any given Buddhist philosophical text, how should we relate them to current philosophical or cognitive scientific uses of the term "concept"? More generally, given that the relationship between the conceptual and the nonconceptual has been one of the central and recurring issues for the 
Buddhist philosophical tradition altogether, can Buddhist philosophy bring fresh insights to our contemporary debates about whether experience has nonconceptual content? And can contemporary philosophy and cognitive science help to illuminate or even resolve some older Buddhist philosophical controversies?

A comprehensive treatment of these questions across the full range of Buddhist philosophy and contemporary philosophy of mind and cognitive science would be impossible. I will restrict my focus to certain core ideas from three strands of Indian Buddhist philosophy - the Abhidharma scholastic philosophers (roughly 150 B.C.E. to 450 C.E.), the epistemological tradition (pramāṇavāda) deriving from Dignāga (ca. 480-540 C.E.) and Dharmakīrti (ca. sixthseventh centuries C.E.), ${ }^{1}$ and the Yogācāra tradition (one of the dominant Indian Buddhist philosophical movements from roughly the fifth century C.E. onwards). I will juxtapose the Buddhist ideas with both cognitive science theories of concepts and the current philosophical debate between conceptualist versus nonconceptualist views of experience.

My approach will be an example of what Mark Siderits calls "fusion philosophy," which he describes as the "counterpoising of distinct traditions" in the effort to solve common philosophical problems (Siderits 2015: xi). In the case at hand, the common problem is to specify what a concept is and accordingly what nonconceptual experience could be.

My presentation has six sections and will proceed as follows. First, I analyze some Abhidharma issues about the relation between nonconceptual sense perception and conceptual cognition. The impetus for my analysis is a recent paper by Robert Sharf (2018). He argues that the structure of the Abhidharma theories of perception cannot help but raise the problem of how to relate nonconceptual sense perception to conceptual cognition and that the way that the Abhidharma philosophers (Ābhidharmikas) frame the problem makes it insoluble. Second, I use cognitive science to clarify and sharpen the problem. Third, I argue that although the problem is intractable within the Abhidharma framework, it may be resolvable using a model of concept formation based on reading Buddhist epistemology (pramānavāda) through cognitive science

\footnotetext{
${ }^{1}$ The term "pramānavāda" means "pramāna theory." A pramāna is an "instrument" or reliable means for obtaining knowledge in the sense of reliable cognition. Pramānavāda is concerned with what constitutes a pramāna. This type of philosophical discourse originally derived from the Brahmanical Nyāya school. See Dasti and Phillips (2017). The Buddhist pramānavāda philosophers (pramānavādins) can also be described as belonging to the Yogācāra-Sautrāntrika movement. For a useful introduction to pramānavāda, see Dunne (2004), chapter 1.
} 
glasses. Fourth, I use this model to present a Buddhist epistemological perspective on the contemporary conceptualist versus nonconceptualist debate. Fifth, I argue that Yogācāra offers a conception of nonconceptual experience that is absent from this debate. In many Yogācāra texts, awareness that is said to be free from the duality of "grasper" (grāhaka) and "grasped" (grāhya) is nonconceptual. The grasper-grasped duality is the subject-object structure of experience. According to the Yogācāra philosophers (Yogācārins), conceptual experience necessarily has a subject-object structure; hence, any experience lacking the subject-object structure must be nonconceptual. None of the contemporary philosophical arguments for nonconceptualism is adequate or suitable for explicating this unique understanding of conceptuality and nonconceptuality. Thus, Yogācāra provides an original perspective on what has been called the problem of the "scope of the conceptual," that is, "how the conceptual/nonconceptual distinction should be drawn" (Laurence and Margolis 2012: 291). For this reason, among others, Yogācāra has something to offer philosophy of mind. ${ }^{2}$ Moreover, using cognitive science, we may be able to render some of the Yogācāra ideas in a new way, while in turn recasting ideas from cognitive science. I illustrate these points using recent behavioural and neuroscientific studies of the effects of Buddhist mindfulness meditation practices on the perception and experience of pain. Sixth, I end by combining Buddhist philosophical ideas with the enactive approach in cognitive science to sketch an enactive perspective on concepts. From this perspective, a concept is not a mental entity by which an independent subject grasps or represents independent objects, but rather one aspect of a complex dynamic process in which the mind and the world are interdependent and co-emergent poles (Varela, Thompson, and Rosch 1991/2017; Rosch 1999; Thompson 2007).

In pursuing these aims, I hope to illustrate Siderits's idea of fusion philosophy and to show the value of thinking about the mind from a cross-cultural philosophical perspective. In Jonardon Ganeri's words, "Philosophy of mind is indeed a transcultural undertaking: the search for a fundamental theory of mind must never limit itself to the intuitions and linguistic practices of any one community of thinkers but should be ready to learn from diverse cultures of investigation into the nature of mind and mind's involvement in world" (Ganeri 2017: 5).

\section{Seeing Blue}

\footnotetext{
${ }^{2}$ I am inspired here by Jay Garfield's approach to relating Yogācāra to philosophy of mind. See Garfield (2015) and (2011a, Part II: Yogācāra). See also Coseru (2012).
} 
In the Abhidharma, the problem of conceptuality versus nonconceptuality centres on how to understand the relation between the sensory grasping of a quality-particular (e.g., a blue qualityparticular) and the mental grasping of an object via a name or mental label. The former (sensory) part of the cognitive process is supposed to be the nonconceptual part; the latter (mental) part of the cognitive process is supposed to be the conceptual part.

The Abhidharma project is to defend the truth of the Buddha's word, as preserved in the Buddhist scriptures, especially the Buddha's teaching that all phenomena arise dependent on causes and conditions, and that no phenomena, singly or collectively, constitute a self, in the sense of an enduring subject of experience or an internal controller of the body and the mind.

In the Buddhist scriptures known as the Nikāyas (the early Pāli language texts containing the teachings attributed to the Buddha), the functioning of the sense organs, plus the kinds of sensory awareness based on them and the associated kinds of feeling or hedonic tone, are distinguished from the perceptual recognition of a qualitative characteristic (e.g., a shape or a colour), but whether these elements are all separate mental events or inseparable parts of one mental event is not clear. It is also not clear whether perception, properly speaking, is the functioning of the sense organs and the associated sensory awareness, or the recognition of a characteristic feature (see Taber 2005: p. 171, n. 78). Consider this passage:

Dependent on the eye and forms, eye-consciousness arises. The meeting of the three is contact. With contact as condition there is feeling. What one feels, that one perceives. What one perceives, that one thinks about. What one thinks about, that one mentally proliferates. With what one has mentally proliferated as the source, perceptions and notions [born of] mental proliferation beset a man with respect to past, future, and present forms cognizable through the eye (Madhupiṇdika Sutta 16. Nāṇamoli and Bodhi 1995: 203). ${ }^{3}$

The Pāli term translated as "perceives" in "what one perceives" is sañ̃na (saṃjña in Sanskrit); it has the sense of recognizing something based on a mark or characteristic (Gethin 2001: 41). Recognition enables perceptual judgement and thought ("what one perceives, one thinks about"). It is not possible to tell from this passage, however, whether a given sensory awareness (e.g., an “eye-consciousness" or moment of visual awareness), the associated "feeling" (vedana , a hedonic sensation that is either pleasant, unpleasant, or neutral), and the associated recognition

\footnotetext{
${ }^{3}$ The text repeats these statements for the remaining four sense organs and objects (ear and sounds, nose and odours, tongue and flavours, body and tangibles) and the mind and mind-objects.
} 
( $\operatorname{sañ\tilde {a}} / \operatorname{samj} \tilde{n} \bar{a})$ arise sequentially or simultaneously. It is also not possible to tell whether these elements are separate "processing stages" or inseparable aspects of one perceptual event. These issues bedevil the Ābhidharmikas and figure in their controversies about perception (Dhammajoti 2007a; 2007 b; Sharf 2018).

To carry out their project of systematizing and defending the Buddha's teaching, the $\bar{A}$ bhidharmikas elaborate a relentless form of reductionism, analyzing the entire universe, including all experienced phenomena, into a set of elementary existents called dharmas. Many scholars now agree that dharmas (according to the Ābhidharmikas) are elementary tropes or quality-particulars, existing at space-time points (Ganeri 2001: 101-102; Goodman 2004; Siderits 2007: 113-118). For example, according to the Ābhidharmikas, a particular pot is blue in virtue of the presence of many miniscule and elementary blue dharmas or blue quality-particulars. (They are elementary in the sense that they have no parts that are themselves blue qualityparticulars.) The pot itself is nothing but a collection or bundle of dharmas. Similarly, a mind is nothing but a bundle of mental dharmas. Indeed, from the ultimate analytical standpoint, there are no pots or minds; there are just bundles of dharmas. It will be important to keep this metaphysical framework in mind as we consider the Abhidharma controversies about perception.

On the one hand, the Sarvāstivāda-Vaibhāṣika (henceforth "Vaibhāṣika") school and the Sautrāntrika school agree that the object is first grasped nonconceptually by the senses and then grasped conceptually by the mind. ${ }^{4}$ The Sarvāstivāda treatise, Collection on Consciousness (Vijñanakaya-śāstra) expresses this view in its statement that the eye-consciousness (visual awareness) grasps only blue, not "this is blue," whereas the mental consciousness can grasp both blue and "this is blue," the latter by way of grasping its name. ${ }^{5}$ This statement that visual

\footnotetext{
${ }^{4}$ The Sarvāstivāda, "Teaching That All Exists," was one of the most influential Abhidharma schools. Its name derives from its thesis that all "conditioned factors" (dharmas) continue to exist (sarvam asti) throughout all three time periods of past, present, and future. The Vaibhāșika ("Followers of the Vibhāṣā") was a Sarvāstivāda subschool active in northwestern India (Kashmir-Gandhāra). It claimed that its principal text (the Abhidharmamahāvibhāsa) was originally spoken by the Buddha. The Sautrāntrika ("Followers of the Sūtras"), who were likely a dissenting Sarvāstivāda offshoot, rejected this claim. They upheld the doctrine of "momentariness" (kșanikavāda), according to which only instantaneous, presentmoment activity exists. See Rospatt (1995).

${ }^{5}$ The Collection on Consciousness (Vijnanakaya) is thought to have been composed in the first century C.E. but exists only in Xuanzang's Chinese translation from 649. Dhammajoti (2007a: 108) translates the passage as follows: "The visual consciousness can apprehend only a blue colour (nīlam), but not 'it is blue' (no tu nīlam iti). Mental consciousness can also apprehend a blue colour. [But] so long as it is not yet able to apprehend its name, it cannot apprehend 'it is blue'. When it can apprehend its name, then it can also apprehend 'it is blue'." Sharf (2018) also translates this passage (and includes the Chinese):
} 
awareness grasps blue, whereas the mind can also grasp "this is blue," becomes a pericope for Indian Buddhist philosophy (Sharf 2018). Vasubandhu (ca. fourth to fifth centuries C.E.) repeats it in his masterwork of Abhidharma thought, Commentary on the Treasury of Abhidharma (Abhidharmakośabhāṣya), which criticizes the Sarvāstivāda-Vaibhāșika view from the Sautrāntrika perspective (Pruden 1991, Volume 2: 425). Dignāga, the originator of the Buddhist logical and epistemological tradition, also repeats it, in his Commentary on the Compendium of Epistemology (Pramānasamuccayavrtti) (Hattori 1968: 26).

The basic idea is that each of the five kinds of sensory awareness has access only to its proper sense object (visual awareness to visual objects, hearing to sounds, and so on), whereas the mental awareness has access not only to mental objects but also to the five senses and their objects. In addition, whereas the visual awareness can grasp only blue, the subsequent mental awareness can also grasp "this is blue"-or, as we might say, "that something is blue" (Taber 2005: 30) — by associating the name "blue" with the sensory content.

On the other hand, the Ābhidharmikas disagree about exactly how the perceptual process works. To bring out their disagreements, recall the passage from the Nikayas quoted above, which begins, "Dependent on the eye and forms, eye-consciousness arises." This might mean that the visual sense faculty and the material visual object precede the arising of visual awareness, or it might mean that the three elements are strictly contemporaneous, such that they arise simultaneously. In addition, if they are contemporaneous, is this a case of simultaneous causation or of some kind of metaphysical dependence relation (perhaps the eye-consciousness supervenes on the eye and forms)? Furthermore, what exactly does the seeing? Is it the eye or the eye-consciousness? And when the passage states, "The meeting of the three is contact. With contact as condition there is feeling," is "contact" another real element (dharma) or just a way of designating the coming together of sense organ, object, and awareness? Finally, even if the sensory awareness grasps merely blue, and not "this is blue," how exactly is this kind of

'Eye-cognition is only able to discern blue; it is unable to discern 'this is blue.' Mind-cognition is also able to discern blue. As long as [mind-cognition] is unable to discern [the color's] name, it is unable to discern 'this is blue.' But should it be able to discern its name, it discerns, at the same time, both 'blue' and 'this is blue.' The colors yellow, red, white, and so on are [analyzed] in the same way as the color blue." Sharf's translation includes the continuation of the passage with the same formula for "sound" and "this is a sound," and he notes that the passage goes on to repeat the formula for nose and odour, tongue and taste, body and touch, and that it concludes by saying that "mind-cognition is also able to discern all dharmas." 
discrimination supposed to be nonconceptual, given that it requires grasping blue versus yellow or white or red, and so on?

The Vaibhāṣikas maintain that "the eye sees," by which they mean that it is the visual organ that sees, but that it can do so only when associated with visual awareness, which depends on the eye as its base (Dhammajoti 2007a: 51-52). They also maintain that the visual organ, the material object, and the visual awareness - all understood as continuants made up of a series of bundles of momentary quality-particulars - arise simultaneously and are "mutually conjoined causes (samprayuktaka-hetu) to one another; the absence of any one renders their very conascence impossible; either they arise all together, or none of them can come into existence at all" (Dhammajoti 2007: 96). According to this view, an episode of sensory awareness registers its object directly, that is, without the mediation of concepts and with no time-lag between its occurrence and the occurrence of the object.

The Sautrāntrikas, however, deny that "the eye sees." They maintain that the seeing is nothing other than the momentary event of visual awareness itself (Dhammajoti 2007a: 55). According to Vasubandhu, there is no agent of seeing; there is just the occurrence of visual awareness as a momentary event in a causal series. We can say that "the visual awareness sees," but we should not be misled by this form of expression into thinking that the grammatical subject of the statement refers to an agent (Kellner 2014: 278-280). The Sautrāntrikas also reject the Vaibhāșika doctrine of simultaneous causation. Rather, the sense faculty and the sense object are the cause of the subsequently arising visual awareness. The momentary awareness occurs after the momentary object; in other words, there is a time-lag between the two, such that the object is no longer present when the visual awareness occurs. ${ }^{6}$ The subsequent awareness is said to resemble or conform to the previously occurring object; specifically, the awareness is said to bear the "form" or "aspect" (ākära) of the object (Dhammajoti 2007b; Kellner 2014). Thus, for the Sautrāntrikas, the awareness of the external object is not direct in the way that it is for the Vaibhāṣikas; rather, the awareness registers the object only after it has disappeared and by way of bearing the object's "form."

In addition, the Vaibhāșikas maintain that "contact" is a real element (dharma) that occurs simultaneously with the arising of the sense organ, the object, and the sensory awareness. They

\footnotetext{
${ }^{6}$ For a helpful discussion of the Sautrāntrika "time-lag argument" in relation to the metaphysics of momentariness, see Siderits (2007: 130-137).
} 
reason that it must be a real element for it to serve as the cause for the arising of feeling (only real entities as opposed to nominal ones have causal efficacy), and that, given simultaneous causation, it can co-exist in the same moment with the sense organ, the object, and the sensory awareness, while being the effect of their convergence.

The Sautrāntrikas reject all of this, arguing that all causal relations require the effect to occur after the cause, that "contact" is just a nominal entity (prajñapti), namely, a way of designating the combination of the sense organ, the object, and the (subsequent) awareness, and that it is this combination that gives rise to feeling.

Despite these disagreements, the Vaibhāșikas and the Sautrāntrikas agree that the full recognition of the object happens only when the mental awareness, which arises subsequent to the sensory awareness and is conditioned by various "mental factors" (caitasika), such as memory and understanding, grasps the content of the sensory awareness. Nevertheless, they disagree about the exact sequence of events and about what is directly versus indirectly grasped.

For the Vaibhāṣikas, the sequence has two stages: first, the sensory awareness arises along with the sense organ and the object; and second, the mental awareness occurs. Whereas the sense organ serves as the sense faculty for the sensory awareness, that initial moment of sensory awareness, which is a mental event, is said to serve as the mental faculty for the subsequently arising mental awareness. For the Sautrāntrikas, the sequence has three stages: first, the sense faculty and object arise; second, the sensory awareness occurs; and third, the mental awareness occurs. In addition, whereas they both agree that the mental awareness does not directly grasp the sense object (as a momentary occurrent, it is gone by the time the mental awareness arises), the Sautrāntrikas maintain that the sensory awareness, too, does not directly grasp the object; rather, it grasps it only indirectly by way of directly bearing the object-form ( $\bar{a} k \bar{a} r a)$ that is caused to arise at stage two of the sequence.

We are now ready to take up the question of what is supposed to be nonconceptual in either version of this sequence. Recall the formula that the visual awareness grasps only blue and not "this is blue." According to the Ābhidharmikas, the visual awareness per se is the awareness of the momentary quality-particular blue. For there to be the perception this is blue, the subsequent moment of mental awareness must take the name (nāma) "blue" as its object along with the sensory content, namely, the blue quality-particular that is the object of the antecedent visual awareness. Whereas this kind of object (called the visaya) lasts only a moment and is gone by the 
time the mental awareness arises, the name (concept) can persist from one moment to the next. It thereby enables the mental awareness to have same "perceptual object" (called the âlambana) from moment to moment, and thus to support the perceptual judgement, "this is blue" (Dhammajoti 2007a: 107-109). More generally, since the sensory awareness per se does not require or involve the application of a name (concept), it is nonconceptual, whereas once the mental awareness takes a name as its object along with the sensory content, the awareness is conceptual.

The problem, however, is that the visual awareness must be able to distinguish between blue, green, yellow, red, white, black, and so on, before the application of the corresponding names (concepts) by the mental awareness. What accounts for this ability? More generally, how is sensory awareness able to distinguish between quality-particulars without the application of concepts corresponding to them (Sharf 2018)?

A generous reading of the Abhidharma answer to this question would see it as trying to differentiate between what we would describe as the sensory discrimination of particulars (the sensory detection of differences between stimuli), the perceptual recognition of kinds, and the mental conceptualization of kinds in linguistic thought; a critical reading would see it as waffling or equivocating. The problem is tied to the semantic range of the Sanskrit word, vikalpa, which is variously translated as "discrimination," "discriminative construction," "concept," “conception," and "imagination." Generally speaking, in later Buddhist philosophy, the term vikalpa refers to the conceptual activities of the mind (manovijñana, the mental consciousness), which is said to operate with mental images ( $\bar{a} k \bar{a} r a)$ whose contents are "generic characteristics" (sāmānyalakșana), in contrast to direct perception (pratyakṣa), which grasps the particular "inherent characteristic" (svalakșana) and is free from thought (concept use). ${ }^{7}$ Given this understanding, it would seem to follow that sensory awareness must be free of vikalpa, and indeed the Abhidharma texts state that this is the case: such awareness is said to be avikalpaka (“devoid of conceptualization”) (Dhammajoti 2007a: 104, 135, n. 58). Nevertheless, as we have seen, sensory awareness must be able to distinguish between quality-particulars. The $\bar{A}$ bhidharmikas are thus forced to concede that there is a kind of rudimentary vikalpa at work in sensory awareness, which they call "intrinsic vikalpa" or "vikalpa per se" (svabhāva-vikalpa).

\footnotetext{
${ }^{7}$ See, for example, the entry for vikalpa in Buswell and Lopez (2014: 970).
} 
One way to understand this kind of vikalpa is that it is a mere discrimination that simply registers or detects the presence of a given quality-particular, such as the presence of a blue qualityparticular, either at exactly the same moment as that particular's occurrence (according to the Vaibhāșikas) or immediately afterwards (according to the time-lag reasoning of the Sautrāntrikas). The Ābhidharmikas distinguish between this kind of bare discrimination and two other types of progressively more complex vikalpa, one using "recollection" (anusmaranavikalpa) and one using "examination" (abhinirūpan̄ā-vikalpa). The "vikalpa through recollection" requires being able to hold the object in mind for more than one moment, and the "vikalpa through examination" applies discursive thought to what is thus held in mind. With this threefold distinction in hand, the Ābhidharmikas are able to explain that when sensory awareness is said to be devoid of conceptualization (avikalpaka), what is meant is that it is devoid of the second and third kinds of vikalpa, but not the first kind, which simply registers qualityparticulars in a coarse way — as in the case of grasping blue versus yellow, and so on - with no mental interpretation or conceptualization. ${ }^{8}$

Nevertheless, these distinctions do not so much solve the problem as restate it (Sharf 2018). On the one hand, no "discriminative construction" (vikalpa) is supposed to be present in sensory awareness; on the other hand, "discrimination per se" (svabhāva-vikalpa) must be present in sensory awareness. On the one hand, every sensory awareness involves not only "feeling" (vedanā) but also an element of "recognition" (samjiñā); on the other hand, this kind of recognition is said to be too weak or too coarse to be the same as the kind of recognition that operates in the mental awareness through contact with a name. In other words, one kind of recognition lies on the nonconceptual side of the divide; the other kind of recognition lies on the conceptual side. These manoeuvres do not bridge the divide; they simply restate it. Clearly, the shuffling of terms and proliferation of scholastic distinctions testify to the recognition of a problem - how to bridge the gap between nonconceptual content and conceptual content—but not to any stable solution.

\footnotetext{
${ }^{8}$ Vasubandhu, in his Commentary on the Treasury of Abhidharma (Abhidharmakośabhāșya), building on the Vaibhāșika analyses, identifies "vikalpa per se" (svabhāva-vikalpa) with the mental factor called vitarka, which is a rudimentary advertence to an object before more refined discrimination and naming or conceptualization (1.33a-b, 2.33a-b). See Pruden (1991: Volume 1, 97, 202-204.) See also Dhammajoti (2007: 97, 105-107) and Sharf (2018)..
} 
Vasubandhu seems to recognize the problem, for he rationalizes the terminological manoeuvres this way: One says that sensory awareness is free from discriminative construction (vikalpa) "in the same way that when a horse has only one foot, one says that it does not have any feet" (Abhidharmakośabhāṣya 1:33a-b. Pruden 1991: Volume 1, 97).

The analogy is telling. A horse with one foot does have a foot, but it does not have any footing and cannot run. The problem is to explain how the horse runs-how cognition worksand for that we need an account that puts together nonconceptual sense perception and conceptualized perception. In short, we need a theory of concept formation-what concepts are and how they get formed. The Ābhidharmikas do not provide such an account. For an account of concept formation, we must turn to Dharmakīrti and his commentators. But first we will take a detour through cognitive science.

\section{A View from Cognitive Science}

Looked at from the perspective of cognitive science, the Ābhidharmikas appear to be grappling with the problem of how to understand the relationship between sensation and thought, including how to distinguish among sensory discrimination, perceptual recognition (which requires typeidentification or categorization), and linguistic thought. A cognitive science perspective can help us to sharpen our assessment of vikalpa in Abhidharma. It will also prepare the way for showing how Dharmakīrti's later model of concept formation not only constitutes a decisive advance beyond Abhidharma but also casts new light on familiar issues in cognitive science.

First, a comment on the term "consciousness" in these discussions is necessary. The Ābhidharmikas do not make any systematic distinction between what we would call "conscious" experience and "unconscious" sensory or cognitive processing. From their perspective, every moment of sensory or mental awareness has a very brief or instantaneous duration, rapidly follows its predecessor, and immediately conditions the occurrence of its successor. Although most of this discrete mental sequence lies below the threshold of ordinary cognition, and so in that sense is unconscious, it is thought to be observable by a highly refined, meditative mental awareness, and so is not unconscious in the sense of being inaccessible in principle to any kind of mental awareness (see Thompson 2015, chapter 2).

Cognitive scientists, in contrast, generally distinguish between conscious experience, on the one hand, and unconscious processing, on the other. Here "conscious" means either useable 
in intentionally guided thought and behaviour (including verbal report), or having a qualitative or phenomenal character. ${ }^{9}$ Thus, "unconscious" can mean either inaccessible to intentionally guided thought and behaviour (including verbal report), or lacking a qualitative or phenomenal character. ${ }^{10}$

We can now turn to sensory processing. Whether such processing is conscious or unconscious (in one or another sense), we need to distinguish between sensory discrimination and categorical perception. The former tracks differences in stimulus magnitudes (e.g., this amount of brightness versus that amount of brightness); the latter tracks differences between kinds (e.g., blue versus yellow, or turquoise versus aqua). Sensory discrimination is not sufficient for categorical perception. For example, being able to tell the difference (discriminate) between two shades of blue that differ in hue, saturation, or brightness in a pairwise comparison is not sufficient for being able to say which shade is which when either one is presented in isolation. Discrimination is psychophysically defined in terms of the just-noticeable difference (JND) or least perceptible difference, which is the amount a stimulus magnitude must be changed for one to notice a difference at least $50 \%$ of the time. (The JND is a statistical measure, because the difference that one notices varies from trial to trial, and hence many trials are needed to determine the JND for a particular subject.) Discrimination, so defined, does not imply that one can repeatedly identify the discriminated stimuli. For example, one may be able to discriminate a particular shade of blue without being able to recognize it immediately afterwards as the shade just presented. Such recognition requires having a perceptual category for the shade and (according to the standard view in perceptual psychology) being able to repeatedly apply a mental representation of that category to what one sees. Thus, recognition, unlike mere sensory discrimination, requires categorical perception. Categorical perception consists in making the same response not only to repeated instances of qualitatively identical presentations (e.g., repeated colour presentations having the same hue, saturation, and brightness) but also to repeated instances of what one takes to be presentations of the same kind (e.g., two presentations

\footnotetext{
${ }^{9}$ Being conscious in the first sense is being "access conscious;" being conscious in the second sense is being "phenomenally conscious." For the "access conscious" versus "phenomenally conscious" distinction, see Block (2002).

${ }^{10}$ Whether there can be qualitative or phenomenal states whose contents "overflow" what is cognitively accessed and available for use in intentionally guided thought and behaviour is a controversial issue. For the "overflow" thesis, see Block (2011). For a critical rejection of the thesis, see Cohen and Dennett (2011).
} 
of blue), and in making a different response to what one takes to be a different kind of presentation (e.g., yellow) (Harnad 2003).

With this distinction between sensory discrimination and perceptual recognition/categorical perception in hand, we can raise a question about the meaning of vikalpa in Abhidharma. Does discriminating between two shades of blue without being able to recognize them individually count as a case of vikalpa, or does vikalpa require recognition and categorical perception? Admittedly, the question is anachronistic. Nevertheless, it is unavoidable, given our aim of "engaging Buddhism" in contemporary philosophy of mind and given that vikalpa is sometimes translated as "discrimination" and sometimes as "concept." So, let's consider the options.

On the one hand, if we render vikalpa as "concept," then we make our Ābhidharmikas skirt incoherence, because the minimal case of vikalpa, namely, svabhāva-vikalpa ("intrinsic vikalpa," "vikalpa per se"), simply registers the presence of a quality-particular. Concepts, however, have generality; they reach beyond particulars, enabling reidentification and grasping something as an instance of a kind. The Ābhidharmikas explicitly distinguish the minimal case of vikalpa per se from the kind of vikalpa that relies on memory (anusmarana-vikalpa). Memory is required for perceptual recognition and concept application, so if vikalpa per se does not involve memory, then it cannot be conceptual.

On the other hand, if we render vikalpa as "discrimination," then we run the risk of losing sight of the fact that the word vikalpa paradigmatically designates some kind of mental construction. For the Ābhidharmikas, this construction is the mental superimposition of kinds and wholes onto a world consisting ultimately only of impartite quality-particulars.

Although the Ābhidharmikas do not exactly distinguish between discrimination and perceptual recognition/categorical perception in the way that we do in cognitive science, they appear to be grappling with something very close to this distinction. Indeed, a charitable way to interpret their terminology is to read it as implicitly making a parallel distinction. Consider again that svabhāva-vikalpa ("vikalpa per se"), which belongs to visual awareness per se, is said to register only blue, and not "this is blue." It is reasonable to take this statement as meaning that sensory awareness per se only discriminates its object—where this means registering or detecting it - without being able to categorize and recognize it. According to this reading, when the Ābhidharmikas assert that the "eye-consciousness" (visual awareness) grasps only blue and 
not "this is blue," they mean that the visual awareness only discriminates (detects) blue but does not recognize "this is blue." And when they assert that mentally grasping "this is blue" requires that the mental awareness grasp the name "blue," they mean that recognizing "this is blue" requires applying a mental representation of the hue category blue. From a cognitive science perspective, this mental representation does not have to be linguistic (many nonlinguistic animals have categorical colour perception: see Thompson 1995, chapter 4). Similarly, in later Buddhist epistemology (pramānavāda), as we will see below, the object of the mental awareness that is needed to grasp "this is blue," is not a linguistic entity (a word) but is rather a nonlinguistic mental representation (a mental image) that is said to be suited to be associated with words.

Recall also that the Ābhidharmikas adhere to the Buddha's word as recorded in the Nikāyas that the bundle of psychophysical events that make up what we ordinarily think of as a person always contains samjjñā (recognition). This word gets variously translated as "perception," "cognition, "recognition," and "ideation." Its basic sense is that of noting something based on a distinguishing mark or characteristic. ${ }^{11}$ In cognitive science terms, this way of grasping an object—via a mark or characteristic that other objects can also be perceived to have-goes beyond mere sensory discrimination and requires categorical perception and the ability to type-identify stimuli. The Ābhidharmikas, however, maintain that the kind of samjiñ $\bar{a}$ present in mere sensory awareness is too weak or coarse to be the same kind of recognition that operates in the mental awareness through contact with a "name." Mental contact with the name "blue" enables the mental awareness to grasp that this characteristic is blue, whereas sensory awareness by itself can grasp only the bare particular blue. Here, too, the Ābhidharmikas seem to have arrived at something like our distinction between mere sensory discrimination and repeatable identification through perceptual recognition/categorical perception.

But is categorical perception a conceptual process? By definition, it involves the recognition of kinds. So, the question is whether kind recognition suffices for conceptuality. This question cannot be answered apart from an account of what concepts are.

\footnotetext{
${ }^{11}$ The formal Theravāda Abhidhamma definition of sañña from Buddhaghosa's (ca. fifth century C.E.) text, Path of Purification (Visuddhimagga XIV:130) is as follows: "Its function is to make a sign as a condition for perceiving again that 'this is the same,' as carpenters, etc., do in the case of timber, and so on. It is manifested as the action of interpreting by means of the sign as apprehended, like the blind who 'see' an elephant... Its proximate cause is an objective field in whatever way that appears, like the perception that arises in fawns that see scarecrows as men." Nāṇamoli (1975: 464). See also Gethin (2011: 41).
} 
In cognitive psychology, a concept is generally described as an organized body of knowledge about a category (a recognizable kind) (Machoury 2009: chapter 1). Here "knowledge" is not used in the factive sense (in which to know something implies that it is the case and one cannot know something that is not the case). Rather, it is used to mean content or information retained in memory and useable in perception, cognition, and action (Machoury 2009: 8). Beyond this consensus, however, cognitive psychologists diverge considerably in their use of the term "concept."

Some psychologists and philosophers consider any process of categorization as equivalent to the employment of a concept (Prinz 2002; Mandelbaum 2017). To categorize is to apply a mental representation of a kind, and such a representation, according to this minimalist viewpoint, meets the minimally sufficient criteria for being a concept, because its content has generality beyond the particular and is reidentifiable. For example, categorizing a visual stimulus as blue suffices for possessing a concept of blue, and the perceptual recognition of blue is accordingly a perception with conceptual content. (As we will see, Dharmakīrti holds a version of minimalism, because he holds that sense perception is always nonconceptual and simply discriminates or registers its object without categorizing it; categorization is the work of conceptualization and requires "mental construction" added to or superimposed onto nonconceptual sense perception. See Dunne (2011) and Dreyfus (2011).)

A more stringent understanding of concepts is that categorization is necessary but not sufficient for concept possession. The principal additional requirements are (i) that the body of knowledge or information about a category be retained by long-term memory; (ii) that the knowledge or information be available for use by higher-order cognitive processes (thinking, reasoning, planning, judging, etc.); ${ }^{12}$ and (iii) that concepts have a compositional structure, so that more complex concepts can be formed by putting together their simpler constituents.

\footnotetext{
12 Thus, Machery (2009: 12) describes how most psychologists understand what a concept is as follows: "A concept of $x$ is a body of knowledge about $x$ that is stored in long-term memory and that is used by default in the processes underlying most, if not all, higher cognitive competencies when those processes result in judgments about $x$." Machery makes the important point that concepts, so defined, are heterogeneous, because the relevant bodies of knowledge can be organized in different ways - around prototypes (typical examples), exemplars (remembered instances of a category), theories (miniature theories about a given domain), or perceptual schemata. An individual typically has several heterogeneous kinds of concepts for each category or kind it recognizes. On this basis, Machery argues that the very notion of concept should be eliminated from the theoretical vocabulary of cognitive science, because the heterogeneity of these differently organized bodies of knowledge implies that the class of
} 
For my purposes here, it will be useful to split the difference, as it were, between the minimalist and the stringent accounts, by describing categorical perception as "protoconceptual." A sensory process is proto-conceptual if it categorizes stimuli into kinds (equivalence classes) that are repeatedly recognizable and can be used or relied on in perception and action. Proto-conceptuality is necessary for conceptuality, but I allow that it may not be sufficient, especially for the philosophical meanings of “concept” I discuss later.

I wish to call attention to three points about proto-conceptuality as a way of bridging back to Abhidharma and forward to the pramānavāda (Buddhist epistemology) and Yogācāra views still to be discussed. First, proto-conceptual processes structure our sensorimotor engagement with the world at a basic and prelinguistic level. We and other animals come equipped with sensorimotor systems that sort the flux of the world into stable, recognizable kinds. For example, our visual system, as well as the visual systems of many other animals, sorts the region of the electromagnetic spectrum to which it is visually sensitive into stable and discrete hue categories.

Second, experimental studies indicate that the perceptual categorization of objects can happen very quickly (13-18 milliseconds) (Potter, Wyble, Hagmann and McCourt 2014), and that it usually happens at the basic level (e.g., blue, banana) rather than at the superordinate level (e.g., colour, fruit) (Potter and Hagmann 2015). This evidence supports a view of perception in which categorization is a very early part of the perceptual process, rather than being a later cognitive operation performed on "raw," uncategorized (and hence non-proto-conceptual) perceptual content (Mandelbaum 2017).

Finally, our recognitional abilities are affectively biased. We orient toward and selectively attend to perceptual kinds or categories (e.g., happy faces, angry faces) that are affectively salient to us as a result of our evolutionary and developmental histories, a phenomenon known as “affect-biased attention" (Todd, Cunningham, Anderson and Thompson 2012). Affect-biased attention is inseparable from approach-versus-avoid action tendencies (Markovic, Anderson, and Todd 2013). It is also possible that the perceptual response to an object's affective salience does not occur after the object has been identified, but rather that affective responses support perception from the moment that stimulation begins (Feldman-Barrett and Bar 2009).

concepts is not a natural kind. A more moderate view is "concept pluralism:" A given concept can have multiple types of structure or each type of structure can be a concept on its own. See Laurence and Margolis (1999). 
These points are readily stateable in the Abhidharma terminology. When sensory "contact" (sparśa) occurs, so too do "feeling" (vedanā) and "perceptual recognition" (samjñ̄a), along with “attentional orienting" (manaskāra), “intention" (cetanā, an intentional or volitional mental or bodily action tendency), and "awareness" (vijñāna). Not every element in this package considered on its own is (in my terms) proto-conceptual. "Awareness" (vijñāna) per se and "feeling" (vedanā) per se are nonconceptual; they discriminate but do not categorize ("awareness" simply registers the bare presence of something, and "feeling" is just a sensation with a hedonic tone of pleasant, unpleasant, or neutral). Nevertheless, the whole package is proto-conceptual, due to its ineliminable recognitional/categorical element (samjjũā).

Although we have now sharpened the terms of the Abhidharma framework with the help of cognitive science, we have not yet addressed the Abhidharma problem of how to bridge the gap between nonconceptual content and conceptual content. Given the Abhidharma metaphysics, this problem is especially acute, because the gap to be bridged is between the discrete and momentary awareness of evanescent quality-particulars and the apparently persisting cognition of apparently persisting and reidentifiable perceptual objects belonging to apparently persisting recognizable kinds. Addressing this problem requires not just the distinction between sensory discrimination and perceptual recognition/categorical perception, but also an account of how discriminatory and recognitional/categorical activities contribute to concept formation. What are the generative principles or mechanisms required for producing conceptual cognitions in a world of particulars? The Ābhidharmikas repeatedly run up against this problem but do not have the means to answer it (Sharf 2018). To make progress we need to turn to later Buddhist epistemology (pramānavāda), specifically the apoha or "exclusion" theory of the YogācāraSautrāntrika philosophical movement.

\section{The Apoha Theory}

The Buddhist philosopher Dignāga (ca. 480-540 C.E.) introduced the Sanskrit term apoha, which means "exclusion," in the context of "Buddhist nominalism" and the problem of universals (Hattori 1968; Siderits, Tillemans, and Chakrabarti 2011). ${ }^{13}$ According to Buddhist nominalism,

\footnotetext{
13 "Buddhist nominalism" is a term used by historical and textual scholars; it is not a term native to the Indian and Tibetan Buddhist philosophical tradition. See Siderits, Tillemans and Charkrabarti (2011) and Siderits (2016: 138-160).
} 
reality consists of nothing but unique and momentary quality-particulars. The human mind, however, has a deeply entrenched tendency to carve up the world into the fictional mental constructs of enduring substantial things belonging to distinct kinds. This happens through a kind of "lumping" and "splitting." We lump some particulars together while splitting them off from everything else. The core idea of the apoha theory is that we cluster some particulars together while overlooking their mutual differences and excluding them from everything else. For example, we call some quality-particulars "blue" by overlooking their mutual differences and excluding them from everything else. According to the apoha theory, what unites them is not any real universal "blueness," but rather that they are all not nonblue. The collection of nonblue things is large and heterogeneous, and there is no reason to suppose that there is any universal "nonblueness," which the things lumped into the collection share. Blue, however, is simply the exclusion of nonblue, so similarly there is no reason to suppose that the things lumped together as "blue" all share a universal; on the contrary, these things are all different from each other in numerous ways, but we ignore these differences by uniting them under the concept "blue." More generally, the basic idea of the apoha theory is that the extension of a concept consists in what is excluded from that which is other, where the operation of "exclusion" (apoha) is understood in psychological terms to be an ignoring of differences and in logical terms to be a kind of negation.

An example from Dharmakīrti can help to illustrate the basic idea. ${ }^{14}$ Several different medicinal plants can be used to reduce fever, and they work differently to produce this effect. They have no single common intrinsic property; what they have in common is just that they cause fever to be lowered in us. We take an interest in this effect, so we ignore all the ways that they differ and use the single word "antipyretic" to refer to them. This word designates a class formed by exclusion, namely, those things that are not non-fever-reducing. To think that the members of this class must all share some intrinsic property in common, namely, "antipyreticness," is to project our cognitive interests onto the world and erroneously to reify an exclusion.

It has become standard to distinguish between "top-down" versus "bottom-up" versions of the apoha theory (Tillemans 2011). A top-down approach uses the tools of logic, such as

\footnotetext{
${ }^{14}$ The example comes from Dharmakīti's major work, Commentary on Valid Cognition (Pramānavārttika), I. 74. See Eltschinger, Taber, Much, and Ratié (2018: 85). See also Siderits (2007: 221-222).
} 
negation operators, to work from linguistic meaning and the generality of concepts down to real particulars, which lack any generality or shared natures, while avoiding any commitment to real universals. A bottom-up approach works from pure particulars up to concepts via causal chains from particulars to the generation of sensed resemblances and to judgements of sameness and difference as the core of conceptual cognition. Dignāga's original version of the apoha theory takes a top-down approach, but Dharmakīrti transforms the theory into a bottom-up account. ${ }^{15}$

The bottom-up account is the one that concerns us here. It has been interpreted as offering a "naturalized" account of concept formation (Dreyfus 2011), and, as such, it helps us to tighten the links between Buddhist theories of concepts and cognitive science. For this purpose, the following elements of Dharmakīrti's account deserve emphasis.

First, because of our bodily constitution and the historical formation of our dispositional tendencies, ${ }^{16}$ we spontaneously experience sensory similarities and dissimilarities in the incessant flux of events. These resemblances and differences are not mind-independently real, but rather are a function of how we spontaneously evaluate things, given our constitution and how things affect us (Dreyfus 2011).

Second, such resemblances provide a basis for the cognitive construction of equivalence classes through the ignoring of differences and the exclusion from that which is other (anyapoha) (see Ganeri 2011). ${ }^{17}$ The most primitive form of an equivalence class is what cognitive scientists would call a "perceptual category" (an object category that can be perceptually recognized, such as "cow," or a quality category, such as "blue"), which enables type-identification, recognition, and perceptual judgement (e.g, "that's a cow," "this is blue"). (Here it is important to avoid terminological confusion. For Dharmakīrti, sense perception-pratyakșa - is nonconceptual and what we ordinarily think of perception is thoroughly conceptual, because the categories we

\footnotetext{
${ }^{15}$ See Tillemans (2011: 54-55) "The major change that happens between Dignāga and Dharmakīti is the use of a causal approach to link language to the world. This causal chain from particulars to perception and finally thought and language is entirely absent in Dignāga and so constitutes a substantial evolution in the theory: indeed, it is arguably a new Apohavāda [apoha theory] that Dharmakīrti has devised." Dignāga's theory was criticized by the Brahmanical philosophers Kumārila (seventh century C.E.) and Uddyotakara (sixth century C.E.). The basic objection is that the theory is circular: to form the idea "noncow," one must already have the idea "cow," so explaining "cow" as "not non-cow" presupposes knowing the meaning of "cow." For these arguments and the Buddhist responses, see Hugon (2011) and Sen (2011). Dharmakīti's bottom-up approach was extensively elaborated in Tibet. For the Tibetan reception of Dharmakīti, see Dreyfus (1997).

${ }^{16}$ For the role that karmic history plays in Dharmakīrti's account, see Prueitt (2018).

${ }^{17}$ Ganeri relates apoha to the concept of a quality space as discussed by Clark (1993; 2000).
} 
recognize in perception are constructed via exclusion. Cognitive scientists use the term "sensation" to refer to what Dharmakīrti means by pratyakṣa.)

Third, Dharmakīrti provides a principled answer to the problem of the "scope of the conceptual" or "how the conceptual/nonconceptual distinction should be drawn" (Laurence and Margolis 2012: 291). The answer consists in providing a way to determine whether a cognitive process is conceptual (involves concept application) and whether mental content is conceptual or nonconceptual: a cognitive process is conceptual if and only if it involves the exclusion operation (apoha), and mental content is conceptual if and only if its content is constructed via exclusion. Since perceptual categories (in the cognitive-science sense) are constructed by exclusion from that which is other, they are conceptual. Thus, Dharmakīrti holds a minimalist view of concepts, according to which object and quality recognition suffice for conceptual cognition.

Fourth, a concept is a mental particular (a representation) whose content can be described in cognitive science terms as prototypical (structured via a prototype) in the sense that it presents its object as belonging to a kind according to the object's having a range of expected qualities and characteristics (rather than satisfying a definition in terms of necessary and sufficient conditions).

Fifth, conceptual cognition is motivationally and affectively biased. Concept formationthe construction of equivalence classes via exclusion-always happens under the influence of past experience and in the approach-versus-avoid context of obtaining the desirable and avoiding the undesirable (Dunne 2011; Prueitt 2018). We are motivated both to focus on certain causal effects as being relevant to our goals and to overlook others as being irrelevant. As a result, conceptual cognition is cognitively and affectively interest-relative and context-dependent.

Sixth, it follows that conceptual cognition necessarily has a subject-object structure. It presents the world as consisting of objects belonging to determinate kinds that can be cognitively grasped by the subject.

Seventh, concepts in the minimalist sense-mental representations of object and quality categories constructed via exclusion — are (as Dharmakīrti puts it) "fit to be associated with words" or "capable of being conjoined with discourse" (Tillemans 1997). The mental representation of object and quality categories does not have to be verbally expressed or designated, or linguistic in form, but language in general and words for kinds or sortals in particular require such mental representations (minimalist concepts). Thus, Dharmakīrti defines 
conceptual thought (kalpanā) as "a cognition in which a representation is fit to be associated with a verbal designation." ${ }^{18}$ His commentators take this definition as implying that there are concepts not actually associated with words and that very young infants and nonhuman animals have such concepts, because they have recognitional abilities but lack language. Thus, minimal conceptuality does not require language; it requires only type-identification and recognition of something as an instance of a kind.

Finally, strictly speaking, according to this Dharmakīrtian view, conceptual cognition is erroneous, because there is no sameness outside of our conceptual constructions via exclusion. Each conceptual cognition, considered as a mental event, is a unique, nonrepeatable particular, but considered in terms of its content, involves a representation of sameness. But there is no real sameness "out there" or "in here," so taking sameness to be real is mistaken. It also follows, according to this view, that the subject-object structure of conceptual cognition is erroneous, for there are no enduring subjects and objects, but only evanescent particulars connected via causeeffect relations. Nevertheless, conceptual cognitions can guide effective action if they successfully track causal regularities.

What follows is a bare-bones outline of Dharmakīti's bottom-up apoha theory. ${ }^{19}$ Our example will be the cognition, "this is blue," which we can imagine thinking or uttering whenever we are presented with a blue patch, such as a blue paint chip or a blue light stimulus in a colour discrimination test. Three streams of discrete and causally efficacious momentary events interact to produce this cognitive episode: the causal stream of material particulars constituting the perceived object; the causal stream of material particulars constituting the sense faculty; and the causal stream of mental particulars constituting the mind. ${ }^{20}$ The theory combines a causal account with an error theory:

First, a particular object arises in contact with the visual sense faculty at a given moment.

\footnotetext{
${ }^{18}$ Dharmakīrti, Drop of Reasoning (Nyāyabindu), I. 5 and Ascertainment of Epistemology (Pramānaviniścaya), I. Ibid., p. 166. Dunne (2011: 87) translates this sentence as "a concept is a cognition with a phenomenal appearance that is capable of being conjoined with a linguistic expression;" Dreyfus (2011: 219) translates it as "conceptualization is that consciousness in which a representation [lit., appearance] is fit to be associated with words." See also Taber (2005: 207-208).

${ }^{19}$ I rely here on Dreyfus (1998: 217-232); Dreyfus (2011); and Dunne (2011).

${ }^{20}$ Dunne (2011: 87). Strictly speaking, the three causal series of particulars are all that ultimately exists; they constitute the perceived object, the sense faculty, and the mind, respectively, only because we conceptualize and conventionally refer to them that way.
} 
Second, this sensory contact causes an image having the "phenomenal form" or "phenomenal aspect" (ākāra) of the object to arise in the mind in the immediately subsequent moment. ${ }^{21}$

Third, this "phenomenal representation,"22 which is a mental particular and is the immediate object of sensory awareness, in conjunction with other mental factors - namely, our interests, expectations, and "traces," "imprints" or "residual impressions" (vāsanās) from previous experience — causes us to judge in the next moment, "this is blue."

The third step is conceptual because it regards things that are in fact unique as being the same via exclusion; the first two steps are free of the exclusion operation and the typeidentifying of particulars, and so are nonconceptual. Moreover, at the third step, error occurs, because the perceiver mistakenly thinks that the content of the judgement is not just a mentally created exclusion but also reflects how the world is in itself. Thus, conceptual cognition, despite being pragmatically efficacious in serving our interests, is inherently erroneous. We overlook the differences that exist between all particulars, think in terms of common properties by mentally constructing kinds through exclusion, and naively take these kinds to be mind-independently real rather than recognizing them as our own inventions.

Let us now put some metaphysical and epistemological flesh on this bare-bones account. For something to be real, it must be a causally efficacious particular. Causal efficacy (arthakriyā) is the criterion for being real and only particulars have causal efficacy. ${ }^{23} \mathrm{~A}$ particular's causal efficacy is not a property it possesses, for particulars are unities in which there is no difference between property and property-possessor. What a particular does is no different from what it is; a

\footnotetext{
${ }^{21}$ For discussion of the differences between the concept of $\bar{a} k \bar{a} r a$ in Abhidharma and in Buddhist epistemology (pramānavāda), see Kellner (2014).

${ }^{22}$ I use this term to render " $\bar{k} k \bar{a} r a, "$ which is variously translated as "image," "perceptual image," "cognitive image," "representation," "phenomenal form," and "phenomenal aspect."

${ }^{23}$ Dharmakīrti, Commentary on Valid Cognition (Pramānavārttika), III.3 (the additions in brackets are from Manorathanandin's twelfth century commentary): "Whatever has causal powers (arthakriyāsamartha), that really exists (paramārthasat) in this context [i.e., when we examine reality]. Anything else is declared to be [just] customarily existent (samvrtisat) [because it is practically accepted through mere conceptual fictions]. These two [i.e., the real and the customary] are [respectively] particulars and universals." Translated by om Tillemans (2017: Section 1.2). Dunne (2004: 392) translates this passage as follows: "In this context, that which is capable of telic function is said to be ultimately real. The other one is said to be conventionally real. They are, respectively, the particular and the universal."
} 
particular's causal efficacy is itself particular and is the same as that particular. ${ }^{24}$ Every causally efficacious particular is unique, momentary, and nonrepeatable. ${ }^{25}$ As a result of our history, bodily constitution (which itself is nothing other than a collection of causally related particulars), and how particulars affect us, we spontaneously experience sensory similarities and dissimilarities in the incessant flux of events. These experienced similarities and dissimilarities are not objective, that is, they do not exist "out there" apart from us. Rather, they are products of our interaction with the world. Put another way, there are no real similarities and dissimilarities; there are only evaluations as of similarity and dissimilarity. Such evaluations, however, are not arbitrary, for they are naturally induced as a result of how causally efficacious particulars affect us, given our constitution and history. To use an example familiar to cognitive scientists, numerous physically distinct combinations of light wavelengths can be perceived as blue, and the same physical stimulus magnitudes can be perceived as dissimilar colours depending on the context. These experienced similarities and dissimilarities are a function of how physical stimuli, given their causal efficacy, affect us, given our neurophysiological constitution and evolutionary and developmental history. Such naturally experienced similarities and dissimilarities provide the nonarbitrary basis on which object and quality categories and linguistic concepts are elaborated.

To cognize "this is blue" requires more than just being able to discriminate blue in the sense of being differentially sensitive to it among other visual qualitative similarities and dissimilarities. As the Ābhidharmikas say, seeing blue is not the same as discerning "this is blue." The latter requires being able to cognize multiple instances as being the same in respect of blue, which is to say that it requires type-identification, categorical perception, and recognition. So there needs to be a way to apply the unique content of a particular phenomenal representation ( $\bar{a} k \bar{a} r a)$ across multiple instances. In other words, there needs to be a way for the content to be "repeatable" or to have "continuity" or "distribution" (anvaya), so that it can be used to construe two or more things as the same and type-identify them. Cognizing "this is blue" is a case of recognition. It requires construing the present visual content as the same as a previously

\footnotetext{
${ }^{24}$ Thus, Dharmakīrti and Buddhist epistemologists generally, like their Abhidharma predecessors, can be understood as trope theorists.

${ }^{25}$ For Dharmakìrti's arguments for the momentariness of all that exists - that particulars cannot endure longer than one instant—see Dreyfus (1998: 60-65); Dunne (2004: 91-97); and Tillemans (2017: Section $1.3)$.
} 
experienced visual content, so that they count as two tokens of the same type. There are two sides to this construal, according to the bottom-up apoha theory (Dunne 2011: 92-93). On the one hand, any given phenomenal representation is a unique particular that arises from unique causes and has unique effects, and thus is excluded from all other particulars, which have their own unique causes and effects. It thereby serves as the basis for excluding the phenomenal representations produced by other particulars. On the other hand, its content must somehow be generalized and distributed across a range of particulars to type-identify them. This generalization happens because the content is taken to resemble the contents of other previous representations, so that their objects are taken to be of the same kind. For Dharmakīrti, this construal of items that are in fact unique as the same because they are taken to resemble each other is what conceptuality is all about. The third stage of his account tells us how us how this conceptual cognition comes about.

Recall that particulars are causally efficacious and we take an interest in certain effects. Some physical particulars cause us to see blue - to have a phenomenal representation of blueand we take an interest in this effect, whether explicitly (say, in painting a room) or implicitly by selectively orienting and attending to blue under certain conditions. Since the physical stimuli are unique, it is not the case that they share the common nature of causing us to see blue. Each stimulus brings about this effect in its own specific way, but we overlook these differences given our interest in the effect and our conditioning from previous experience. We are sensitive to the effect but not to the differences in the objects that cause it. As a result of our conditioning, when a particular phenomenal representation occurs, it activates a "trace," "imprint," or "residual impression" ( $v \bar{a} s a n \bar{a})$ from a previous experience, so that the object causing the present experience (the present phenomenal representation) is taken to be the same as the object that caused the previous experience (the previous phenomenal representation). More precisely, the content of the present phenomenal representation is construed to be the same as the content of the previous phenomenal representation, and hence their objects are taken to be the same. All that these objects actually share, however, is their difference from those things that do not bring about this effect, and this difference is just a negation. More precisely, all that these phenomenal representations actually share is their difference from those representations that do not activate this imprint, and this difference is just a negation. Thus, the sense of sameness across multiple instances is based on applying a particular type of negation, namely, the exclusion (negation) of 
those representations that do not have the expected effect. It is this exclusion (negation) that applies across multiple instances, despite every phenomenal representation being a unique particular. Thus, construing things as the same-type-identifying them-comes from combining that which is not distributed (lacks repeatability/anvaya) with that which is distributed. The phenomenal representation as a unique particular lacks repeatability or distribution. The exclusion as a negation is repeatable and has distribution across many phenomenal representations. Neither the phenomenal representation alone nor the negation alone is sufficient for type-identification. Rather, it is the phenomenal representation construed through the exclusion of that which does not have the expected effects that provides the basis for typeidentification (Dunne 2011: 94).

To say that certain things that we call "blue" are excluded from other things because those other things do not have the expected effects - for example, they do not produce a phenomenal representation with a "cool" feeling but rather with a "warm" one-implies that all those things that are excluded have the same effects (the ones we expect). But what exactly are these same effects? We cannot just say that they consist in the production of the same kind of phenomenal representation, because that would imply that there is some pre-existing type-identification of phenomenal kinds, and we are assuming that phenomenal representations are unique mental particulars and have no common natures. In other words, if we take the objects that we call "blue" to be the same because we take their effects - the phenomenal representations they bring about - to be the same, what is the basis for our taking these phenomenal representations to be the same, given that they are supposed to be unique particulars?

Dharmakirti's answer is that we take the phenomenal representations to be the same because they all cause us to judge perceptually "this is blue," where this judgement is conditioned by antecedent and historically formed dispositions (Dunne 2004: 109-126; Prueitt 2018). In other words, we take the representations to be the same because they all produce the same effect, namely, the same perceptual judgement. The perceptual judgement takes as its object the phenomenal content of the representation and construes it as being the same in each case. The construal of sameness depends on the imprints left by previous experiences. Perceptually judging "this is blue" is a case of recognition, because the perceptual judgement takes as its object the content of a present phenomenal representation and construes it as the same as the content of a previous representation whose imprint the present representation 
activates. As John Dunne explains: "It is the placement of this imprint that crucially allows for the fundamental 'unification' or 'construal as the same' (ekikarana) which is the principal marker of conceptual cognition in Dharmakīrti's system" (Dunne 2011: 100). Thus, according to Dharmakīrti's bottom-up apoha theory, the causal chain runs from unique particulars (grouped together because they are excluded from other things that do not have the expected effects) to unique phenomenal representations (grouped together because they are excluded from other representations that do not have the expected effects) to the making of the same perceptual judgement. Going in the reverse top-down direction, the resulting sameness of perceptual judgement warrants taking the phenomenal representations to be the same (type-identifying them), and taking the phenomenal representations to be the same warrants taking their objects to be the same (type-identifying them).

This answer to the question of how we take the phenomenal representations to be the same, however, raises another question: what makes the perceptual judgements the same? If objects are taken to be the same only because they produce the same effects, namely, phenomenal representations that are taken to be the same, and phenomenal representations are taken to be the same only because they produce the same effects, namely, the same perceptual judgement, then what warrants taking the perceptual judgements to be the same? If we say that the perceptual judgements are taken to be the same only because they in turn produce the same effects, then we look to be facing a vicious infinite regress.

Dharmakīrti stops the regress because he maintains that the perceptual judgements are taken to be the same not because they have the same effects, but simply because they present their contents as the same; in his terms, they "cover over" each phenomenal content with a "nondifference." 26 Once we arrive at perceptual judgement, and thus conceptual cognition, the differences between the phenomenal representations that cause the perceptual judgements are simply overlooked. The content of the phenomenal representation, as an object of perceptual judgement/conceptual cognition, is said to lack the vividness or clarity it has as a sensory representation of its object, and so it is easily conflated with the contents of other representations, especially given the priming or biasing that occurs as a result of the activation of

\footnotetext{
${ }^{26}$ Dharmakīrti, Commentary on Valid Cognition (Pramānavārttika), I.109 and his auto-commentary Pramānavārttikasvopajñavrtti (also called Svavrtti), translated by Dunne (2011: 97) and Dunne (2004: 123-124).xw
} 
the imprints of previous experiences (Dunne 2011: 87, 101). As philosophers often say, "explanations must come to an end somewhere" (Wittgenstein 1958: 3), and here the end is to assert that it is just the nature of particulars to cause us to make perceptual judgements of sameness and difference as a result of the causal chain described.

Śākyabuddhi (ca. 660-720 C.E.), an early commentator on Dharmakīrti, gives an analysis of the three meanings of "exclusion of other" (anyāpoha), which we can use to summarize the bottom-up apoha theory (Katsura 2011; Dunne 2004: 131-144). The first meaning is the excluded particular. It is excluded from that which is other in the sense that it is unique and completely distinct from every other particular. The second meaning is the exclusion itself - the "mere exclusion" or "mere negation" that is distributed or continuous across all its instances. It is a purely mental construction, a selective differentiation, based on taking one of the differentiations afforded by the unique particular and biased by an imprint, and making it into a kind or type. The third meaning is the excluded phenomenal representation ( $\bar{a} k \bar{a} r a)$, which serves as the basis for the overlooking of differences, the construction of sameness through the selective negation or exclusion from that which is other, and the object of perceptual judgement/recognition/conceptual cognition.

The bottom-up apoha theory thus purports to give a comprehensive account of conceptual cognition, beginning with the object of sense perception (the particular), which gives rise to a mental representation, which in turn gives rise to a perceptual judgement (a conceptual cognition), which in turn supports action (Dunne 2004: 127-128, 131-132). At the heart of this account is what John Dunne calls a "Janus-faced" theory of concepts (Dunne 2011: 104). A concept is a combination of a mental representation - the phenomenal representation - and a mental operation - the exclusion or negation. Considered as a mental event, a concept is a mental particular. Considered as a mental operation, a concept is a negation or exclusion that is distributed over and applies to multiple instances. Considered phenomenologically, a concept is a mental image, that is, conceptual cognition as a subjective experience is an experience mediated by a mental image. ${ }^{27}$ Cognizing "this is blue" involves recalling a particular mental image (recallable thanks to an imprint) that serves as an exemplar from memory and a prototype of

\footnotetext{
27 "Likewise, the sameness established by exclusions actually applies to the cognitive images; hence, our conceptual cognitions are actually presenting an image as the same as other images, and not a particular as the same as other particulars" (Dunne 2004: 139).
} 
what one expects, and on the basis of which one forms the appropriate exclusion (non-blue) and its complement (the class of things like the paradigm), thereby enabling recognition (matching the perceptual object to the remembered image/paradigm) (Patil 2011).

It is important to note that the subjective experience of conceptual cognition is not of the present image as such, that is, of the present image as a mental particular. Indeed, were one to have a direct experience of the present phenomenal representation as a unique mental particular without selectively excluding it from that which is other, then the experience would be nonconceptual. Rather, in the subjective experience of conceptual cognition, one experiences the content of the phenomenal representation as indistinct from the recalled paradigm and one erroneously takes that generic content to be a real object belonging to a real kind.

Our initial reason for examining Dharmakirti's account was to see how it can be read as a solution to the Abhidharma problem about the relation between nonconceptual awareness and conceptual cognition. The bottom-up apoha theory constitutes a decisive advance beyond Abhidharma because it gives an account of concept formation that includes a principled criterion for specifying which experiences are conceptual and which are nonconceptual. If it is possible and sometimes legitimate to speak of philosophical progress, relative to a tradition of inquiry and its concerns, as I believe it is, then the bottom-up apoha theory of concept formation qualifies as a case of philosophical progress.

Moreover, the theory continues to have importance for us today. It is possible, as we have seen, to describe the theory in cognitive science terms and to present it as providing an answer to the question of the scope of the conceptual. Conceptual mental states are ones that result from exclusion; nonconceptual mental states are ones that do not undergo exclusion. Recognizing "this is blue" is conceptual; merely seeing (detecting or discriminating) blue is nonconceptual. The difference between these two kinds of experience is not explained using fractionations of the one theoretical term vikalpa (svabhāva-vikalpa/vikalpa per se versus anusmaranavikalpa/vikalpa-cum-recollection and abhinirūpaṇa-vikalpa/vikalpa-cum-examination). Rather, it is explained in terms of the presence versus absence of causal chains involving exclusion (apoha).

Unlike the Abhidharma viewpoint, according to the bottom-up apoha account, grasping "this is blue" does not, strictly speaking, require grasping the name "blue," but it does require having a mental representation ( $\bar{a} k \bar{a} r a)$ that is suited to be associated with the name "blue," 
though this association is entirely conventional (a different word could have been used in setting up our colour-naming conventions). The bottom-up apoha theory thus purports to bridge the gap between nonconceptual content and conceptual content by providing a naturalistically interpretable account of concept formation, according to which causal chains from particulars to mental events and residual impressions that function as exemplars and prototypes lead to the formation of perceptual categories that are fit to be linked to words through linguistic conventions.

Of course, Dharmakīti's theory raises a whole host of new questions, which were the focus of intense analysis and debate over many centuries in India and Tibet, and have sparked new discussions using the tools of modern logic and formal semantics. ${ }^{28}$ This attention testifies to the theory's continuing importance, far beyond its being merely an advance on Abhidharma in the Buddhist philosophical tradition, and thus is another indication of the philosophical progress the theory achieved.

My intention is not to defend Dharmakīrti's extreme nominalism - his refusal to accept that there are real (mind-independent) resemblances. Rather, my interest is in his idea that exclusion - the selective ignoring of differences - undergirds conceptual cognition. My aim is to bring this idea, and the apoha theory of concept formation more generally, to bear on philosophy of mind and cognitive science. The rest of this paper will pursue this aim, beginning with the conceptualist versus nonconceptualist debate in contemporary philosophy.

\section{Conceptualism Versus Nonconceptualism}

In the simplest terms, conceptualism is the thesis that all mental states are conceptual states, and nonconceptualism is the contradictory thesis that not all mental states are conceptual states. Stated this way, it is easy to see that the debate is hostage to how we specify what concepts are. Although I will focus on experiential mental states, we can allow for unconscious mental states (according to the two senses of "unconscious" mentioned above, namely, inaccessible to intentionally guided thought and behaviour, and lacking a qualitative or phenomenal character). Whether mental content must be conceptual or can be nonconceptual is the usual way of putting the issue between conceptualism and nonconceptualism. To say that it must be conceptual means

\footnotetext{
${ }^{28}$ For coverage of these questions and approaches, see Siderits, Tillemans, and Charkabarti (2011). See also Dreyfus (1998) and Arnold (2012).
} 
that the subject cannot have mental contents without having the concepts required to specify them; to say that it can be nonconceptual means that the subject can have mental contents while lacking the concepts required to specify them. Nevertheless, the conceptual-versusnonconceptual distinction can be drawn in another way, as between kinds of mental states rather than kinds of mental contents (Heck 2000). According to this way of drawing the distinction, the debate is about whether there are mental states that do not depend on conceptual states or that have different causal or functional roles from those of conceptual states (even if they do not have a different type of content from conceptual states). My concern, however, is with mental content. Moreover, given that content differences between mental states can be understood as a special kind of state difference, if there are mental states with nonconceptual content, it follows that there are nonconceptual mental states (Laurence and Margolis 2012: 292-293). Hence, I will understand the two positions as follows: according to conceptualism, a subject's conceptual capacities determine the contents of all its mental states (all its mental contents are a function of the concepts it possesses); according to nonconceptualism, a subject's conceptual capacities do not determine the contents of all its mental states (some of its mental contents are not a function of the concepts it possesses).

The philosophical notion of a concept at play in this debate differs from the cognitive science notion of a concept as an organized body of knowledge. Philosophers describe concepts as the constituents of thought. Although there is no generally accepted philosophical account of what concepts are, we can point to some generally agreed upon requirements.

First, concepts have generality, that is, they reach beyond particulars by enabling one to recognize a particular as an instance of a general kind of thing. Second, concepts are systematically related, that is, being able to use concepts implies being able to apply the same concept to different things and different concepts to the same thing. Third, concepts are freely combinable to form new thoughts. Finally, these requirements, taken together, imply that concepts are compositional, that is, that their formal structure and semantic content are a function of the formal structure and semantic content of their parts.

Gareth Evans's “generality constraint” is often cited in this context (Evans 1992: 100-105). His idea is that to possess a given concept one must be able to use it in thought in all the 
meaningful combinations into which it could enter with the other concepts one possesses. ${ }^{29}$ Thus, if one can think that $a$ is $F$ and $b$ is $G$, one must be able to think that $a$ is $G$ and $b$ is $F$. The generality constraint has been taken to imply that conceptual content presents the world as being made up of states of affairs, that is, as being made up of individual things belonging to kinds and standing in various relations to each other. It follows that if experience can present the world as not carved up in this way, that is, as not carved up into states of affairs that serve as the truthconditions for propositional judgements, then experience can be said to have nonconceptual content (Cussins 2003).

Nonconceptualists accordingly point to various ways that our experience of the world outstrips or does not depend on our ability to specify what we experience (the contents of our experience) in terms of propositional judgements. The following kinds of experience are the ones usually mentioned: (1) As discussed above, we can discriminate many particular determinate qualities, such as particular shades of colour, that we cannot hold in memory and re-identify (type-identify and recognize) (Raffman 1995; Kelly 2001). (2) Our experience of being located in a global and orientable space, whose directions are intrinsic and body-centred, is not a function of our conceptual capacities, but rather is a form of intuition (in the Kantian and Husserlian sense of an experience that presents the object itself without the mediation of thought), and is a condition of possibility for the perceptual recognition and conceptualization of things in space (Hanna 2005, 2008; Allias 2009). (3) Conscious experience is for a subject; it belongs to the content of a conscious experience that it is given to the subject. This kind of subjectivity or experiential self-specification is independent of having a self-concept and being able to use the first-person pronoun (Bermudez 1998; Zahavi 2005; Musholt 2015). (4) In absorbed, skillful pursuits and "flow states," we are acutely sensitive to the world and have an experiential, activity-based knowledge, but one that presents the world as a milieu of attractions and repulsions, not as a domain of objects and properties that would stand as the truth-conditions of judgements (Cussins 2003; Dreyfus 2005, 2013).$^{30}$ (5) The background affect of existential moods, such as anxiety, despair, and joy, affect how the whole world seems or feels, but not in a way that seems adequately expressible by any propositional judgement (Ratcliffe 2008).

\footnotetext{
${ }^{29}$ Atomists about concepts, such as Jerry Fodor, reject this idea and maintain that whether one has a particular concept is independent of the other concepts one may have. See Fodor (1998). See Fodor (2007). For discussion, see Balog (2009).

${ }^{30}$ A locus classicus for this idea is Merleau-Ponty (1963: 168-169).
} 
It is important to note that the nonconceptualist motivation here is to call attention to forms of experience that do not show the kind of generality, systematicity, and freely recombinable structure of conceptual thought and its expression in linguistic judgement. The motivation need not be to provide an immediate, nonconceptual, ground of justification for knowledge, so there need be no allegiance to the so-called epistemological "myth of the given" (Hurley 1997).

In response to these kinds of nonconceptualist considerations, John McDowell (2009) has revised the conceptualist position. He proposes that for an experience to be the exercising of a conceptual capacity, it is not necessary that the experience have a propositional content. Rather, its content can be a structured unity while being nondiscursive. Nevertheless, he maintains that such an experience is conceptual in its being conceptualizable. Although much of our lives may proceed without conceptualized thoughts, we can nonetheless "embrace" all of it in thought. McDowell (1994) earlier argued that we can form "demonstrative concepts," such as "that blue," to pick out particular qualities and that such concepts are as fine-grained as the perceptual experiences are. The conceptualist might also observe that we can conceptualize and describe in detail the experiential contours of body-anchored, egocentric space versus allocentric space; that we have a rich conceptual repertoire for describing and teaching skillful activities; and that we have various concepts of emotions and moods that we bring to bear in describing how we experience the world when we are anxious, depressed, or elated.

Nonconceptualists, however, argue that this line of thought is beside the point. On the one hand, if to "embrace" such experiences in thought means just that we can think about them, such embrace does not imply that the experiences themselves are conceptual or concept-dependent. Nonconceptualists maintain that not everything presented in an experience is conceptualized; to accept this thesis is tantamount to accepting that there is nonconceptual content (Crane 2013). Whether we are always in a position to go on to conceptualize such content, where that means to make use of it in discursive thought and judgement, is a further question. On the other hand, if to "embrace" in thought means to present such contents themselves to thought, then concepts are insufficient in the absence of having the relevant nonconceptual experiences. For example, according to the nonconceptualist reading of Kant, the nonconceptual intuition of space is a necessary condition of possibility for being able to cognize objects in space (Hanna 2005, 2008; Allias 2009). Furthermore, in the case of fine-grained perceptual discriminations, the nonconceptualist argues that even if we can use a demonstrative to indicate "that blue" in the 
presence of an instance of a particular shade of blue, we cannot deploy that demonstrative content recognitionally. In other words, we cannot use it to reidentify that particular blue no matter how brief the time interval between the first and second presentations. This limitation on the content calls into question its credentials as a concept. In Dharmakīrti's terms, the mental content lacks distribution (anvaya); it cannot be distributed or repeated over its instances, so it fails the crucial test for being a concept. To put the point another way, our ability to discriminate that particular shade of blue is independent of our ability to remember it, so it cannot be the case that our ability to experience it depends on our having a recognitional demonstrative concept for it; therefore, the content is nonconceptual.

The conceptualist may reply that this line of reasoning is faulty because it commits the "conceptualization fallacy," namely, "supposing that when conceptualization occurs given a prior representational state that the prior state isn't itself conceptual" (Laurence and Margolis 2012: 295). The thought here is that "the conceptualization involved needn't be based on an unconceptualized state, but might itself be a matter of reconceptualization (i.e., a move from one type of conceptualized representation to a different conceptualization)" (ibid.).

Although we should guard against this faulty reasoning, it does not apply in the present context. We are supposing that concepts are either systematic and freely combinable constituents of thought, or mental representations that can be held in memory to enable perceptual recognition. Conceptualists bear the burden of showing that the kinds of experiential content at issue are conceptualized in one of these ways and then reconceptualized. At a minimum, they must show that the experiential content is generalizable or has repeatability (anvaya) across a range of instances, so that it can be used to type-identify particulars.

The bottom-up apoha theory provides a useful perspective on this debate because of the way that it delineates the scope of the conceptual. Type-identification or recognition of something as an instance of a kind is necessary and sufficient for conceptual cognition. Merely seeing (discriminating) this blue is not a conceptual cognition and does not require possessing the concept "blue." Recognizing this blue is a conceptual cognition and requires possessing a concept of blue. Such a concept is constructed via exclusion and is repeatable or has distribution across a range of instances. Mere demonstrative content-detecting this blue-is not sufficient for possessing a recognitional demonstrative concept that enables one to re-identify the shade in 
a subsequent moment. Possessing such a concept requires "mental construction" (kalpanā) through the bottom-up exclusion (apoha) process.

Buddhist epistemologists (Yogācāra-Sautrāntrikas) are nonconceptualists, both according to the above definition of nonconceptualism (mental contents are not entirely determined by the concepts one possesses) and according to their own account of conceptual cognition. They hold that perception (pratyaksa) is representational and that not all representational content is conceptual content. Perception is of its object as that object is phenomenally presented in a mental image, but the mental content is not conceptualized until the image is conflated with the content of a residual impression and undergoes exclusion from that which is other.

This Buddhist version of nonconceptualism is unique and offers a perspective not found in our contemporary debate. On the one hand, experience contains and causally depends on nonconceptual content. On the other hand, ordinary experience of the world - the content of everyday experience taken at face value - is thoroughly conceptualized, because it is constructed by the exclusion process. Hence, we are hardly ever aware of nonconceptual content as such. Indeed, such awareness would require either taking the exclusion process offline, as it were, which requires inhibiting or overcoming the motivational and affective biases that drive exclusion, or it would require allowing the exclusion process to operate but without getting caught up in its falsification of reality, that is, without mistaking its inherently erroneous representations for how things really are..$^{31}$

We can put these ideas in Kantian terms. Ordinary perceptual experience results from what Kant calls "synthesis," the putting together of representations to produce a single mental content. For the Buddhist epistemologists, synthesis or "mental construction" (kalpanā) takes the form of the moment-to-moment conflation of the content of a particular mental image with the contents of residual impressions functioning as expectation-recognition exemplars and prototypes. For Kant, synthesis in general is the result of the imagination and is not the same as conceptualizing (only the "synthesis of recognition in a concept" involves concept application, and whether the two other forms of synthesis - "apprehension in intuition" and "reproduction in imagination"are concept-dependent is a contentious interpretative issue). For the Buddhist epistemologists, however, all aggregation involves mental construction. Only momentary particulars ultimately

\footnotetext{
${ }^{31}$ For further discussion, see Griffiths (1990); Dunne (1996 and Ram-Prasad (2000).
} 
exist but the mind (the stream of momentary mental particulars) creates the impression of there being enduring substances that come sorted into determinate kinds. This kind of "mental construction" (kalpanā) is inextricably both imaginational (it conflates mental images) and conceptual (it deploys the logical operation of exclusion/negation and iterates it across multiple instances). ${ }^{32}$ It is also fundamentally erroneous, because it presents a false representation of the world. It follows that a nonerroneous or undistorted cognition would have to be nonconceptual (though, as we will see, it does not follow that a cognition is undistorted simply in virtue of being nonconceptual or that there cannot be distorted nonconceptual cognitions). But what exactly would such a cognition be like for the subject? I now turn to this question.

\section{Nonconceptual Awareness}

The Ornament of the Great Vehicle Sutras (Mahāyānasūtrālamkāra), a major work of Yogācāra philosophy traditionally attributed to Maitreyanātha ("Protector Maitreya," an epithet of the future Buddha, Maitreya) and said to be received by the philosopher Asanga (ca. fourth century C.E.), Chapter XI: 31, states:

False imagination, neither correct

Nor false, not conceptual, Not conceptual and not nonconceptual-

This characterizes all objects of cognition (Dharmachakra Translation Committee 2014: 327).

The principal Indian and Tibetan philosophical commentators_-Vasubandhu, Sthiramati (475555 C.E.), and Mipham (1846-1912) — explain this verse using a threefold distinction between (i) ordinary dualistic awareness, (ii) nonconceptual and nondualistic awareness, and (iii) awareness subsequent to nonconceptual and nondualistic awareness. "False imagination" refers to ordinary cognition, which is dualistic. Everything in ordinary awareness is falsely imagined to be really divided into a cognitive subject — the "grasper" (grāhaka) — and an object of cognition — that which is "grasped" (grāhya). Liberation or awakening requires overcoming this fundamental delusion. "Neither correct nor false" refers to the period when one hears and reflects on the Buddha's teaching. One's cognition is incorrect, because it is still dualistic, but it is not entirely

\footnotetext{
${ }^{32}$ Thus, it is not surprising that translators of Buddhist philosophical texts sometimes translate vikalpa and kalpanā as "imagination." For further discussion, Matilal (1986: 312-313) and Urban and Griffiths (1994).
} 
ignorant, because it is informed by the Buddha's teaching that the subject-object dualism is a false mental imposition. "Not conceptual" refers to the fully awakened, direct, nonconceptual realization of all phenomena (including that very realization) being "empty" (śünya) of subject and object. Thus, "nonconceptual" here means "nondualistic." Finally, "not conceptual and not nonconceptual" refers to the so-called "mundane wakefulness" that is attained in the wake of the nonconceptual, supreme awakening. This condition is called the "subsequent awareness" or "subsequently obtained worldly awareness." It enables the awakened one (the bodhisattva) to act and teach in the everyday world. It is not conceptual, because it does not engage in any dualistic reification of subjects and objects. Nevertheless, since it completely understands and directly cognizes all phenomena as empty of subject and object, it is not merely nonconceptual; it is also nondualistic. Exactly what this means, however, especially in the case of the Buddha, who is said to have attained a state free of all conceptualization and desire, is far from clear and proved to be a very thorny philosophical and religious issue for the tradition (Dunne 1996; Tzohar 2016). What could motivate the Buddha to teach, if he lacked all desire, and how could he teach anything without employing conceptual cognition?

My purpose here is not to delve into those difficulties. Rather, I am going to assume that Yogācārins are committed to nondualistic awareness being an attainable experience, and not just a soteriological ideal. Nevertheless, I would like to distinguish between this kind of experience in its normatively and soteriologically ideal type - the sustained nondualistic awareness of which the Buddha and advanced bodhisattva are supposed to be capable - and the possibility of shorter, maybe even rather brief, episodes of nonconceptual awareness with an attenuated subject-object duality, of which we ordinary beings may be capable. ${ }^{33}$ Similarly, I would like to distinguish between the ideal form of the "subsequent awareness" and the possibility of more ordinary forms, which would ensue after brief moments of nonconceptual awareness with an attenuated subject-object duality. I propose that we may be able to use the philosophical and cognitive science ideas already presented to make sense of such moments of nonconceptual awareness and subsequent awareness, where by "make sense," I mean in a broadly naturalistic and psychologically plausible way.

\footnotetext{
${ }^{33} \mathrm{I}$ am indebted to Jowita Kramer for discussion of this idea.
} 
Vasubandhu is the philosopher responsible for using the phrase, "grasped and grasper" (grähyagrāhaka), specifically as a gloss on the term, "duality" (Gold 2015: 158-169). Yogācārins assert that the nature of reality (dharmatā) is nondual and that dualities are unreal mental fabrications. Vasubandhu takes the grasper-grasped duality as the fundamental unreal and mentally fabricated duality. "Grasper" refers to consciousness (vijñanna), understood as a causally produced moment of awareness, and "grasped" refers to the object that appears to consciousness. Described phenomenologically, the grasper-grasped structure is the apparent subject-object structure of ordinary awareness; more precisely, it is the apparent subject-object structure of intentionality, especially of what philosophers today call "phenomenal intentionality," the mental directedness upon an object that is taken to be characteristic of (and, according to some philosophers, constituted by) consciousness. ${ }^{34}$

Vasubandhu rejects one of the key, agreed-upon assumptions of the contemporary conceptualist versus nonconceptualist debate, namely, that the subject-object form of intentionality or mental-directedness is a real, intrinsic feature of episodes of conscious awareness or cognition and that it accurately reflects reality. Rather, for Vasubandhu and the Yogācārins in general, subject-object intentionality is an illusory distortion of and imaginary superimposition onto phenomena that lack this structure. For the Yogācārins, ordinary intentional experience is delusional; it not only experiences things in terms of the subject-object structure but also takes this structure to be an accurate representation of reality. ${ }^{35}$

My concern here is not to examine the Yogācāra arguments for this viewpoint, but rather to see what sense can be made of the possibility of a less than fully enlightened form of experience with an attenuated grasper-grasped structure. As we saw in our discussion of the bottom-up apoha theory, conceptual cognition, according to this theory, necessarily has a subject-object structure, because it presents the world as consisting of objects belonging to determinate kinds that are cognitively grasped by the subject. So, one might be led to think that the subject-object dualism results from conceptualization, specifically that it is a function of "exclusion" (apoha). The thought would be that the mental operation of "exclusion from that which is other" is responsible for the subject-object structure.

\footnotetext{
${ }^{34}$ For a study of intentionality and consciousness in Buddhist philosophy, see Coseru (2012).

${ }^{35}$ For an important discussion of this theme, Garfield (2011b).
} 
Although the (non-Buddhist) Pratyabhijñā Śaiva philosophers, Utpaladeva (ca. 925-975 C.E.) and Abhinavagupta (ca. 975-1025 C.E.), who build on Dharmakirti, take this route and consider that the mere exclusion of subject from object, and vice-versa, makes the subject-object dualism a conceptual construction, this is not Dharmakìrti's view (Prueitt 2017). On the contrary, he maintains that the grasper-grasped duality is nonconceptual. In other words, he maintains that the subject-object structure is an unreal appearance or illusion that already distorts nonconceptual awareness before conceptualization happens. In Dharmakirti's terms, the grasper-grasped duality arises from an "internal distortion" (antarupaplava) of the mind, not from misconstruing the object (the momentary particular) through a perceptual judgement of sameness (Dunne 2004: 88$89,315-317)$. So, the absence of the grasper-grasped duality entails the absence of conceptuality, but the absence of conceptuality does not entail the absence of the grasper-grasped duality. Conceptual cognition requires the subject-object structure, because conceptuality requires the mental construction of equivalence classes "out there" versus equivalence classes "in here." For example, recognizing (type-identifying) this blue requires both that it is seen as being qualitatively the same as that (previously seen) blue, and that the subject of this seeing is taken to be the same as the subject of that (previous) seeing, or to use a more minimalist Buddhist formulation, that this seeing and that seeing are taken at least to belong to the same psychophysical causal series. Nevertheless, according to Dharmakīti and the Yogācārins in general, the presence of the subject-object structure does not by itself entail the presence of conceptuality, because the subject-object structure is already present as an "internal distortion" of nonconceptual awareness.

Dharmakīrti, when writing from a Yogācāra viewpoint, likens the presence of the graspergrasped duality to the apparent presence of floaters in the visual field. ${ }^{36}$ The error or distortion is nonconceptual, because it is already given in the particular phenomenal image, prior to combining the image with an exclusion (vyāvrtti, apoha) and making a perceptual judgement of sameness based on the supposed similarity of the content of the image to that of previous experiences. Whereas ocular floaters are caused by a defect in the eye, the apparent presence of the grasper-grasped duality is caused by a defect in the mind (the mental causal series), namely,

\footnotetext{
${ }^{36}$ Commentary on Valid Cognition (Pramānavārttika), III. 217. See Dunne (2004: 409). For further discussion, see Prueitt (2017: 23-34). For a discussion of Buddhist philosophical thinking about perceptual illusion versus cognitive errors, see Coseru (2012: 182-191).
} 
our fundamental ignorance (avidyā). Someone who lacks the concepts to think about the distortion caused by having ocular floaters can still suffer from their presence and the visual impairment that they cause. Similarly, the grasper-grasped duality already distorts ordinary awareness before conceptual cognition ensues. Thus, nonduality, the absence of the dualistic appearance of subject and object, which occurs when ignorance is eliminated, implies nonconceptuality, but mere nonconceptuality, the absence of the construction of sameness/difference classes through exclusion — does not imply nonduality. Nonduality requires transcending ignorance and the dualistic appearance of subject and object (the grasper-grasped duality), which are already present in ordinary nonconceptual awareness prior to conceptualization.

This discussion suggests that one way to interpret the "subsequent awareness" would be to understand it as somehow allowing for awareness of and action in the world but without the presence of the dualistic illusion of subject and object. A further question would be whether the "subsequent awareness" could involve a kind of recognitional cognition and use of language that somehow do not presuppose or rest on this dualistic illusion. Perhaps there is a way to allow conceptualization to return — or, as we might also say, to come back online — but without instinctively, as it were, grasping onto it as real, that is, without immediately and spontaneously reifying it.

In any case, my concern is less with the nondual awareness and subsequent awareness as soteriological ideals and more with whether we can make sense of brief and limited or attenuated versions of these types of awareness.

I propose the following hypothesis. There can be moments of alert and acute awareness with highly attenuated affective and motivational biases of attention, highly attenuated attentional selection and attentional inhibition, and highly attenuated approach-versus-avoid action tendencies. To the extent that such attenuation occurs, the habitual grasper-grasped duality of experience will be weakened. In other words, there will be less habitual interpretation of mental content as presenting an independent subject encountering an independent object, and more experience of mental events as transitory mental occurrences situated within a field of embodied awareness. In this way, the dualistic subject-object structure of phenomenal intentionality will be reduced and there will be less reification of mental content. Such moments of experience may arise spontaneously or be induced through various practices, can be of 
variable duration, and can have effects on subsequent cognition and action. From a cognitive science perspective, this hypothesis is testable. Whether the "subsequent awareness" arising from such experiences is psychologically beneficial, according to one or another conception of wellbeing, is also testable. Whether it is soteriologically beneficial is not empirically testable, but rather is a question for religion and philosophy.

Empirical evidence from studies of the effects of mindfulness meditation practices on pain supports my hypothesis. The experience of pain has a sensory aspect, an affective aspect, and a cognitive aspect. The sensory aspect consists of the discriminability, localization, and felt intensity of the pain stimulus; the affective aspect consists of the emotional and motivational significance of the stimulus and the degree of experienced unpleasantness; and the cognitive aspect consists of the meaning of the stimulus - how the stimulus is appraised and the memories and anticipations it evokes. Studies examining mindfulness meditation, specifically the type of practice that cognitive scientists call "open monitoring" meditation (Lutz, Slagter, Dunne and Davidson 2008; Lutz, Jha, Dunne, and Saron 2015), which cultivates a nonreactive awareness without attentional selection and attentional inhibition, indicate that this type of practice influences the sensory, affective, and cognitive aspects of pain in meditators compared to control subjects (Grant 2014). The findings include long-term Tibetan Buddhist practitioners, long-term Zen practitioners, long-term Vipassana practitioners, and meditation-naïve individuals who receive four days of training in a secular breath-awareness form of mindfulness practice. ${ }^{37} \mathrm{~A}$ general finding across all the long-term mindfulness practitioners is a significant decrease in the self-reported unpleasantness of painful stimuli and a correlated reduction in neural activity in brain areas known to be associated with affective and cognitive aspects of pain, compared to control subjects, together with either no significant difference in the pain sensory intensity ratings between the meditators and the control subjects (in the case of the Tibetan Buddhist and Vipassana meditators) or reduced sensory intensity ratings for the meditators (in the case of the Zen practitioners). In other words, during the cultivation of an open, nonselective, and nonbiased awareness, stimulus intensity is accurately discriminated while experienced unpleasantness is

\footnotetext{
${ }^{37}$ For the Tibetan Buddhist practitioners, see Perlman, Solomon, Davidson, and Lutz (2010); Lutz, McFarlin, Perlman, Salomons, and Davidson (2013). For the Zen practitioners, see Grant and Rainville, (2009); Grant, Courtemanche, and Rainville (2011). For the Vipassana practitioners, see Gard, Hölzel, Sack, Hempel, Lazar, Vaitl, and Ott (2012). For the meditation-naïve individuals, see Zeidan, Martucci, Kraft, Gordon, McHaffie, and Coghill (2011).
} 
reduced. Importantly, this effect does not occur during the practice of "focused attention" meditation, in which one places one's attention selectively on an object, such as the breath or a mental image, and thereby in effect distracts oneself from the pain sensation. A further finding is that the long-term meditation practitioners, but not the control subjects, show an increase in neural activity in brain areas known to be associated with the sensory aspect of pain. This finding is striking because "no other known pain modulator reduces pain and at the same time results in increased activity of pain-related brain regions" (Grant 2014: 58). Finally, in the study with the meditation-naïve individuals, mindfulness practice led to reductions in both pain-intensity ratings and unpleasantness ratings, with reduced neural activity in sensory brain areas and increased activity in areas associated with affective and cognitive aspects of pain. This pattern of results compared to those found for the long-term meditators has been interpreted as suggesting "that beginners cannot inhibit automatic appraisal of their experience and actively reappraise it within the framework of mindfulness, whereas more experienced practitioners may actually achieve something closer to no appraisal" (Grant 2014: 60).

Taken together, these results suggest that the long-term meditators have learned to decouple the alert monitoring of sensory events from the processes that lead these events to be anticipated and experienced as unpleasant (Grant 2014: 59). In other words, they have learned to unbias their attention to salient sensory events from habitual affective and motivational influences and approach-versus-avoid action tendencies (Davis and Thompson 2015). More generally, the results suggest that the long-term meditators have learned to cultivate a kind of vigilance that consists not in sustained concentration on a particular object, as happens in the case of "focused attention" meditation, but rather in what the Tibetan Buddhist Mahāmudrā meditation tradition, which is strongly influenced by Yogācāra, calls "mindfulness consisting in mere non-distraction" (Dunne 2015). In this style of practice, the meditator cultivates an awareness that disengages from the dualistic appearance of grasper and grasped and the approach-versus-avoid framework of obtaining the desirable and avoiding the undesirable. As we have seen, this dualistic framework is precisely the context required for concept-formation and conceptualization to occur, according to Dharmakīrti. Viewed from a cognitive science perspective, vigilance as present-moment centred "mere non-distraction" can be expected to attenuate autobiographical memory-dependent processes (Dharmakīrti’s imprints/vāsanās) (Fujino, Ueda, Mizuhara, Saiki, and Nomura (2018), the formation of mental narratives, self- 
related evaluations, and anticipatory self-projections, all of which involve conceptualization and are strongly concept-dependent.

Of course, given that the meditators are evaluating and reporting their perceptions of sensory intensity and their experiences of the degree of unpleasantness, conceptualization must be present. Furthermore, it is not possible to know from these experiments the extent to which the long-term practitioners versus the control subjects categorize or conceptualize the stimuli as "pain," and whether decreased conceptualization of the stimuli as "pain" predicts decreased unpleasantness, though this seems likely, given that the long-term practitioners are apparently minimizing appraisals of the stimuli.

Another possibility is that the long-term meditators are engaging in an alternative conceptualization, one that conceptualizes the experience of the stimulus simply as a transitory mental event, rather than conceptualizing it by selectively attending to its content and construing that content as representational (as presenting an accurate depiction of reality). This alternative way of conceptualizing experience has been called "dereification," and is a typical part of mindfulness meditation practices (Lutz, Jha, Dunne, and Saron 2015). Dereification is the construal of thoughts, feelings, and perceptions as mental processes rather than as accurate representations of reality. Deification has been shown to reduce the effects of motivational states and traits on appetitive behaviours in approach-versus-avoid contexts, not only during formal practice sessions but also over subsequent time periods, in both the laboratory and in the field, and has been shown to have distinct neural correlates. ${ }^{38}$

Although dereification presumably is an effortful conceptual procedure in novice practitioners, it may eventually become effortless and nonconceptual (in the sense of not requiring active conceptualization) in experienced practitioners. Indeed, according to the bottomup apoha theory, if dereification has become so thorough that the experienced meditation practitioner directly experiences the stimulus simply as a unique particular without any selective exclusion from that which is other, then the experience is nonconceptual.

Investigating these issues requires that cognitive scientists, clinical scientists, philosophers, Buddhist scholars, and experienced meditation practitioners work together. In particular, more

\footnotetext{
${ }^{38}$ See Papies, Barsalou, and Custers (2012); Papies, Ponk, Keesman, and W. Barsalou (2015); Abis, Papies, Gopinath, Cabanban, Quigley, Krishnamurthy, Feldman-Barrett, and Barsalou (2015); and Baquedano, Vargara, Lopez, Fabar, Cosmelli and Lutz (2017).
} 
attention needs to be given to the cross-cultural philosophical issues about concepts discussed in this paper to clarify and advance the empirical investigation of mindfulness meditation practices. Although the issues discussed in this paper are primarily philosophical and exegetical, they have significant bearing on current research in the neuroscience of meditation. Without attention to these issues, the neuroscience of meditation runs the risk of using the terms "conceptual" and "nonconceptual" in vague and uncritical ways.

To return to the main point, the empirical evidence just discussed is consistent with the hypothesis I proposed above. Open monitoring meditation appears to attenuate affect-biased attentional selection and attentional inhibition, affect-biased appraisal and anticipation, and approach-versus-avoid action tendencies. ${ }^{39}$ In Yogācāra terms, it weakens the grasper-grasped duality.

Of course, we cannot know simply from the Yogācāra texts themselves whether their authors practiced anything like open monitoring meditation as described here. On the one hand, it would be anachronistic at best and grossly inaccurate at worst to suppose that they did engage in open monitoring meditation as described here, because this practice has been strongly shaped by "Buddhist modernism." ${ }^{40}$ On the other hand, from a cognitive science viewpoint informed by Buddhist philosophy and concerned with basic principles of human cognition, it seems eminently plausible to suppose that the Yogācāra philosophers would have been familiar with meditation methods for weakening (and, in their view, ideally freeing oneself from) the grasper-grasped duality of what we would call affectively and motivationally biased cognition.

We can now return to the conceptualist-versus-nonconceptualist debate. None of the cases of nonconceptual experience that the nonconceptualist adduces is equivalent to the case of alert and acute awareness in which affectively biased perceptual categorization and approach-versusavoid tendencies are either absent or attenuated, and hence conceptualization (exclusion from that which is other) is either absent or attenuated. In other words, none of the cases is equivalent to experiences in which the grasper-grasped duality is either absent or attenuated. Thus, the Yogācāra viewpoint provides an important and new (to the Western perspective) nonconceptualist framework.

\footnotetext{
${ }^{39}$ See also Fucci, Abdoun, Caclin, Francis, Dunne, Ricard, and Davidson (2018).

${ }^{40}$ See Sharf $(1995,2015)$ and McMahan (2008).
} 
At the same time, the cognitive science viewpoint on attuned skillful action may work as a model for the Yogācāra conception of the "subsequent awareness" (Tzohar 2016). Some characteristics of highly skilled action are unbiased and effortless attention, present-moment sensitivity, and spontaneous receptivity without anticipatory approach-versus-avoid tendencies (Slingerland 2003, 2014; Bruya 2010). Jay Garfield (2006) thinks that this idea of action in the world without the grasper-grasped duality is more strongly developed in East Asian Buddhism than in Indian and Tibetan Buddhism, and he describes its full development and understanding as one of the reasons that "Bodhidharma had to go to the East."

It should be noted, however, that the idea of efficacious action without the grasper-grasped duality is one that the conceptualist may be able to acknowledge. Indeed, one way to think of the "subsequent awareness" is that it allows for a conceptual embrace or acknowledgement of nondualistic awareness. After all, one mark of great mastery is being able to conceptualize an experiential, activity-based practice or skill so as to teach others effectively.

One conceptualist position congenial to these ideas comes from Alva Noë (2014). Following Wittgenstein, his view is that concepts are not mental particulars but rather "techniques by which we secure our contact with the world" (ibid.: 2), that understanding consists of the mastery of such techniques, and that there are many modes of understanding, of which judgement is only one. We should not make judgement be the model for all understanding. There are forms of understanding, such as the practical understanding displayed in skillful action, in which we are not able, as a general rule, to formulate judgements adequate to capture what we do. Nevertheless, Noë argues, such modes of understanding are conceptual, because they require the use of concepts, understood not as mental representations of categories, but rather as techniques for having access to the world.

My reservation about this viewpoint is not that it recasts concepts in Wittgensteinian terms as techniques of access to the world but rather that it leaves no place for nonconceptual awareness. On the one hand, it may be that we cannot properly speak of understanding in the absence of conceptuality, and hence that nonconceptual awareness is not a form of understanding. One may worry, however, that by rendering every form of attunement to the world a form of understanding, Noë stretches the notions of understanding and conceptuality too far, so that they become vacuous. On the other hand, even if nonconceptual awareness does not count as a form of understanding, it does not follow that it is not a form of experience (where, in 
Kantian terms, "experience" includes sensuous intuitions that do not need to be brought under concepts in order to present us with particulars: see Allias 2009). Moreover, to suppose that nonconceptual awareness may be embraceable by one or another mode of understanding does not entail that it is itself conceptual.

\section{An Enactive Approach to Concepts}

The paradox is that conceptual understanding must embrace precisely that which transcends conceptual understanding: "the grasping mind cannot grasp its ultimate inability to grasp; it can only cultivate its tolerance of that inability" (Thurman 1976: 161). Likewise, the conceptual mind cannot conceive its inability to conceive, but it may be able to cultivate a tolerance of that inability and let itself be open to the nonconceptual.

Such tolerance requires changing our view of concepts. Instead of taking concepts to be internal mental representations of an independent outside world, we can take them to be elements of a complex dynamic process in which the mind and the world are interdependent and coemergent poles. Instead of asking how concepts represent the objective world inside the subjective mind, we can ask how mental concepts and object categories co-arise and mutually specify each other. This approach is the enactive approach to concepts, based on the idea from enactive cognitive science that cognition fundamentally is the enactment or bringing forth of relevance through embodied action (Varela, Thompson and Rosch 1991/2017; Rosch 1999: Thompson 2007; Chatterjee 2011).

From an enactive perspective, cognizer and cognized are opposite poles of the same event. Continuous and reciprocal causal interactions between the cognitive being and its environment, over developmental and evolutionary timescales, produce affordances — perception-action saliences - that become recognition-expectation prototypes around which categories form. Eleanor Rosch explains the enactive perspective as follows:

Since the subjective and objective aspects of concepts and categories arise together as different poles of the same act of cognition and are part of the same informational field, they are already joined at their inception. They do not need to be further joined by a representational theory of mind... Concepts and categories do not represent the world in the mind; they are a participating part of the mind-world whole of which the sense of mind (of having a mind that is seeing or thinking) is one pole, and the objects of mind (such as visible objects, sounds, thoughts, emotions, and so on) are the other pole. Concepts - red, chair, afraid, yummy, armadillo, and all 
the rest - inextricably bind, in many different functioning ways, that sense of being or having a mind to the sense of the objects of mind (Rosch 1999: 72, italics in original).

Using the enactive perspective, we can recast the bottom-up apoha theory (Chatterjee 2011). Concepts in the mind and categories in the world co-arise through the activity of exclusion, under the influence of past experience, dispositions, motivational tendencies, and our body-given sense of similarities and dissimilarities. Dharmakīrti's theory can be cast as offering a way to understand out how this co-arising happens. To recapitulate: Given our bodies - and, we can add, our culture-we pay selective attention to a certain perception-action salience $x$, which prominently stands out for us against the background of what we take to be non- $x$, such that we arrive at the dichotomy of $x$ and non- $x$. Should our selective attention be drawn to non- $x$, we can make further divisions - $y$ and non- $y, z$ and non-z, and so on. Strictly speaking, each member of non- $x$ is different from every other one, but we overlook these differences and take some members to be compatible with each other. We treat them in the same way, thus forming equivalence classes through the operation of exclusion from that which is taken to be other.

This kind of exclusion already happens at the most fundamental sensorimotor level. Our body conflates differences and superimposes equivalences on them, thereby generating invariants of sensorimotor response. Crucially, these sensorimotor invariants or equivalence classes are based on similarities of response and not on intrinsic similarities. The members of any given equivalence class $C$ are similar because they evoke the same response; they do not evoke the same response because they are similar in themselves. ${ }^{41}$

Language requires such a stable sensorimotor world, in particular for our associating words with objects (such as colour terms with hue categories). From a cognitive science perspective, however, we can also allow that language possession may drive concept formation and category recognition, so that the exclusion process may not be only bottom-up, but rather may be both bottom-up and top-down with "looping effects" (Fauconnier and Turner 2003).

Amita Chatterjee summarizes this enactive verson of the apoha theory as follows:

Naming or the use of words (nāma-yojanā) paves the way for explicit learning and hastens the process of manipulating thought contents. Organisms become more and more skilful in abstraction... But even at this stage, we cannot claim that we have cut up the world at its natural

${ }^{41}$ For an extended and trenchant discussion of this point, see Matthen (2005). 
joints or that our putative kinds are real natural kinds, since the external constraints come to us only in the form of affordances at the sensory-motor level. Our linguistic descriptions are somehow grounded in our sensory-motor invariants. Without implicit categorization, explicit categorization or learning cannot take place, yet that is no guarantee for grasping the world as it is. Dharmakirti and some of his followers therefore rightly recognized the role of significant errors behind successful human practices. Cognitive scientists are not at all bothered by this kind of antirealism, because they do not presume to do ontology at all. If they do ontology, then they restrict their ontic claims to their terms of art (Chatterjee 2011: 252-253).

From an enactive perspective, however, concepts are not inherently erroneous, as they are for Dharmakīrti. Dharmakīrti's view of concepts as erroneous rests on what has been called his "scheme-content dualism," namely, "that we can and should make a clear and radical separation between what our linguistic-conceptual schemes create and impose upon an uninterpreted content and that content itself, which is real, accessible only to perception, outside the conceptual scheme, and hence free of the scheme's distortions and coloring" (Tillemans 2011: 51). ${ }^{42}$ Given this viewpoint and Buddhist nominalism, concepts cannot but be inherently distorting, despite whatever pragmatic efficacy they may have in serving our ends.

According to the enactive approach, however, concepts are a functional part of situations and have a participatory role in structuring them (Rosch 1999). To borrow Hilary Putnam's words, "the mind and the world jointly make up the mind and the world" (Putnam 1981: xi). The basic function of concepts is not to identify mind-independent things but to bring forth and stabilize saliences as figures on a ground, relative to the cognitive being and its mode of coupling with the world. Viewed from this perspective, as Chakrabarti and Siderits note, exclusion from that which is other "is not a logical operation we perform on sensory input, but a node in the interactive interplay of organism and environment" (Chakrabarti and Siderits 2011: 44), or an equilibrium of a dynamical system comprising organism and environment. For the enactive approach, "there is nothing that a concept actually is; our notion of a concept merely picks out one facet of a complex dynamic process" (ibid.). In short, if we use the enactive approach to recast the bottom-up apoha theory, then "the concept of a concept is the reification of a dynamic process in which mental particulars play a role and which can be analyzed post-hoc in terms of rule-governed behavior. This dynamic process is consistent over time for a cognizer, as well as across cognizers, because it leads to action that satisfies the interests of cognizers" (ibid.: 46).

\footnotetext{
42 The "scheme-content dualism" idea comes from Donald Davidson (1984).
} 
Here it no longer makes sense to suppose that concepts are inherently erroneous, because the scheme-content dualism underpinning this assessment has been abandoned in favour of a kind of pragmatism. ${ }^{43}$ What we call "concepts" are to be evaluated according to their efficacy in the pursuit of our aims and not according to how they represent a transcendent reality.

What about the nonconceptual? As Rosch notes, "Concepts only exist against a nonconceptual background. We could not even think to talk about concepts and conceptualization without some contrast of what they are not" (Rosch 1999: 75). From the enactive perspective, the co-arising of concepts (mind) and categories (world) presupposes a nonconceptual background against which they emerge. Nonconceptuality provides the inexhaustible field within which conceptuality functions.

The obvious worry is that this contrast is a conceptual one, that it comes about through exclusion: the conceptual is that which is not nonconceptual, and the nonconceptual is that which is not nonnonconceptual. Here we need to remember that the concept of a concept is a reification of a dynamic process. The nonconceptual—nominalized and made into a concept —is also a reification. Nevertheless, if there is nothing that conceptuality actually is other than evolving nodes of a dynamic process, then there is nothing that nonconceptuality actually is other than everything else that makes these nodes possible.

\section{References}

Abis, Lauren A. M., Esther K. Papies, Kaundinya Gopinath, Romeo Cabanban, Karen S.

Quigley, Venkatagiri Krishnamurthy, Lisa Feldman Barrett, and Lawrence W. Barsalou. 2015. A shift in perspective: decentering through mindful attention to imagined stressful events.

Neuropsychologia 75: 505-524.

Allias, Lucy. 2009. Kant, nonconceptual content, and the representation of space. Journal of the History of Philosophy 47: 383-413.

\footnotetext{
${ }^{43}$ For a discussion of scheme-content dualism in relation to Putnam's "internal realism," see Thompson(1991).
} 
Arnold, Dan. 2012. Brains, Buddhas, and Believing: The Problem of Intentionality in Classical Buddhist and Cognitive-Scientific Philosophy of Mind. New York, NY: Columbia University Press.

Balog, Katalin. 2009. Jerry Fodor on non-conceptual content. Synthese 170: 311-320.

Baquedano, Constanza, Rodrigo Vargara, Vladimir Lopez, Catalina Fabar, Diego Cosmelli and Antoine Lutz. 2017. Compared to self-immersion, mindful attention reduces salivation and automatic food bias. Nature Scientific Reports 7 Article number: 13839 doi: 10.1038/s41598$017-13662-z$

Bermudez, José Luis. 1998. The Paradox of Self-Consciousness.Cambridge, MA: MIT Press.

Block, Ned, 2002. Concepts of consciousness, In Philosophy of Mind: Classical and Contemporary Readings, ed. David Chalmers. 206-218. New York: Oxford University Press.

Block, Ned. 2001. Perceptual consciousness overflows cognitive access. Trends in Cognitive Sciences 12: 567-575.

Bruya, Brian ed. 2010. Effortless Attention: A New Perspective in the Cognitive Science of Attention and Action. Cambridge, MA: MIT Press.

Buswell, Robert E. and Donald S. Lopez, eds. 2014. The Princeton Dictionary of Buddhism. Princeton, NJ: Princeton University Press.

Chakrabarti, Arindam and Mark Siderits. 2011. Introduction. In Apoha: Buddhist Nominalism and Human Cognition. Siderits, Mark, Tom Tillemans, and Arindam Chakrabarti, eds. New York: Columbia University Press.

Clark, Austen. 1993. Sensory Qualities. New York: Oxford University Press. 
Clark, Austen, 2000. A Theory of Sentience. New York: Oxford University Press.

Chatterjee, Amita. 2011. Funes and categorization in an abstraction-free world. In Apoha:

Buddhist Nominalism and Human Cognition, in Siderits, Mark, Tom Tillemans, and Arindam Chakrabarti, eds. 247-257. New York: Columbia University Press.

Cohen, Michael and Daniel Dennett. 2011. Consciousness cannot be separated from function. Trends in Cognitive Sciences 15: 358-364.

Coseru, Christian. 2012. Perceiving Reality: Consciousness, Intentionality, and Cognition in Buddhist Philosophy. Oxford: Oxford University Press.

Crane, Tim. 2013. The given. In Mind, Reason, and Being-in-the-World: The McDowell-Dreyfus Debate. Joseph Shear, ed. 229-249. London: Routledge Press.

Cussins, Adrian. 2003. Content, conceptual content, and nonconceptual content. In Essays on Nonconceptual Content. York H. Guenther, ed. 133-164. Cambridge, MA: MIT Press.

Davidson, Donald. 1984. On the very idea of a conceptual scheme. In Donald Davidson, Inquiries into Truth and Interpretation. 183-198. Oxford: Clarendon Press.

Dasti, Matthew and Stephen Phillips. 2017. The Nyāya-sütra. Selections with Early Commentaries. Indianapolis, IN: Hackett Publishing Company.

Davis, Jake and Evan Thompson. 2015. Developing attention and decreasing affective bias. In Handbook of Mindfulness: Research, Theory, and Practice, Kirk Warren Brown, J. David Creswell, and Richard M. Ryan, eds. 42-61. New York: Guilford Press.

Dhammajoti, K. L. 2007a. Abhidharma Doctrines and Controversies on Perception. Hong Kong: Centre of Buddhist Studies, University of Hong Kong. 
Dhammajoti, K. L. 2007b. Ākāra and direct perception (pratyakșa), Pacific World Journal 3: 245-272.

Dharmachakra Translation Committee, trans. 2014. Ornament of the Great Vehicle Sütras. Maitreya's Mahāyānasūtrālamkāra with Commentaries by Khenpo Shenga and Ju Mipham. Snow Lion.

Dreyfus, Georges. 1997. Recognizing Reality: Dharmakirti's Philosophy and Its Tibetan Interpretations. Albany, NY: State University of New York Press.

Dreyfus, Georges. 2011. Apoha as a naturalized account of concept formation. In Apoha: Buddhist Nominalism and Human Cognition, in Siderits, Mark, Tom Tillemans, and Arindam Chakrabarti, eds. 207-227. New York: Columbia University Press.

Dreyfus, Hubert. 2005. Overcoming the myth of the mental: How philosophers can profit from the phenomenology of everyday expertise," Proceedings and Addresses of the American Philosophical Association 79: 47-65.

Dreyfus, Hubert. 2013. The myth of the pervasiveness of the mental. In Mind, Reason, and Being-in-the-World: The McDowell-Dreyfus Debate. Joseph Shear, ed. 15-39. London: Routledge Press.

Dunne, John D. 1996. Thoughtless Buddha, passionate Buddha. Journal of the American Academy of Religion LXIV: 525-556;

Dunne, John D. 2004. Foundations of Dharmakirti's Philosophy. Somerville, MA: Wisdom Publications.

Dunne, John D. 2011. Key features of Dharmakīrti's apoha theory. In Apoha: Buddhist Nominalism and Human Cognition, in Siderits, Mark, Tom Tillemans, and Arindam Chakrabarti, eds. 84-108. New York: Columbia University Press. 
Dunne, John D. 2015. Buddhist styles of mindfulness: A heuristic approach. In Handbook of Mindfulness and Self-Regulation. Brian D. Ostafin, Michael D. Robinson, and Brian P. Meier, eds. 251-270. New York: Springe..

Eltschinger, Vincent, John Taber, Michael Torsten Much, and Isabelle Ratié. 2018.

Dharmakirti's Theory of Exclusion (apoha). Part 1. On Concealing. An Annotated Translation of Pramāṇavārttikasvavṛ̣tti 24, 16-45, 20 (Pramāṇavārttika 1.40-91). Studia Philologica Buddhica. Mongraph Series XXXVI. Tokyo: The International Institute for Buddhist Studies of the International College for Postgraduate Buddhist Studies.

Evans, Gareth. 1992. Varieties of Reference. Oxford: Oxford University Press.

Fauconnier, Gilles and Mark Turner. 2003. How We Think: Conceptual Blending and the Mind's Hidden Complexities. New York: Basic Books.

Feldman-Barrett, Lisa and Moshe Barr. 2009. Seeing it with feeling: Affective predictions during object perception. Philosophical Transactions of the Royal Society of London B Biological Sciences 364: 1325-1334.

Fodor, Jerry. 1998. Concepts: Where Cognitive Science Went Wrong. Oxford: Oxford University Press.

Fodor, Jerry. 2007. The revenge of the 'given'. In Contemporary Debates in Philosophy of Mind, eds. Brian P. McLaughlin and Jonathan Cohen, eds. 105-116. Oxford: Blackwell Publishing.

Fucci, E., O. Abdoun, A. Caclin, A. Francis, J. D. Dunne, M. Ricard, and R. J. Davidson. 2018. Differential effects of non-dual and focused attention meditations on the formation of automatic perceptual habits in expert practitioners. Neuropsychologia 119: 92-100. 
Fujino, Masahiro, Yoshiyuki Ueda, Hiroaki Mizuhara, Jun Saiki, and Michio Nomura. 2018. Open monitoring meditation reduces the involvement of brain regions related to memory function. Nature Scientific Reports 9: 9968. DOI:10.1038/s41598-018-28274-4

Ganeri, Jonardon. 2001. Philosophy in Classical India. London: Routledge Press.

Ganeri, Jonardon. 2011. Apoha, feature-placing, and sensory Content. In Apoha: Buddhist Nominalism and Human Cognition, Siderits, Mark, Tom Tillemans, and Arindam Chakrabarti, eds. 228-246. New York: Columbia University Press.

Ganeri, Jonardon. 2017. Attention, Not Self. Oxford: Oxford University Press.

Gard, Tim, Britta K. Hölzel, Alexander T. Sack, Hannes Hempel, Sara W. Lazar, Dieter Vaitl, and Ulrich Ott. 2012. Pain attenuation through mindfulness is associated with decreased cognitive control and increased sensory processing in the brain. Cerebral Cortex 22: 2692-2702.

Garfield, Jay. 2001a. Empty Words: Buddhist Philosophy and Cross-Cultural Interpretation. New York: Oxford University Press.

Garfield, Jay. 2001b. Vasubandhu's Treatise on the Three Natures: A translation and commentary. in Jay Garfield, Empty Words: Buddhist Philosophy and Cross-Cultural Interpretation. 128-151. New York: Oxford University Press.

Garfield, Jay. 2006. Why did Bodhidharma go to the East? Buddhism's struggle with the mind in the world. Sophia 45: 61-80.

Garfield, Jay. 2015. Engaging Buddhism: Why It Matters to Philosophy. New York: Oxford University Press.

Gethin, R. L. M. 2001. The Buddhist Path to Awakening. Oxford: Oneworld Publications. 
Gold, Jonathan. 2015. Paving the Great Way: Vasubandhu's Unifying Buddhist Philosophy. New York: Columbia University Press.

Goodman, Charles. 2004. The Treasury of Metaphysics and the physical world. The Philosophical Quarterly 54: 389-401.

Grant, Joshua A and Pierre Rainville. 2009. Pain sensitivity and analgesic effects of mindful states in Zen meditators: A cross-sectional study. Psychosomatic Medicine 71: 106-114.

Grant, Joshua A., Jérôme Courtemanche, and Pierre Rainville. 2011. A non-elaborative mental stance and decoupling of executive and pain-related cortices predicts low pain sensitivity in Zen meditators. Pain 152: 150-156.

Grant, Joshua A. 2014. Meditative analgesia: The current status of the field. Annals of the New York Academy of Sciences 1307: 55-63.

Griffiths, Paul J. 1990. Omniscience in the Mahāyānasūtrālañkāra and its commentaries. IndoIranian Journal 33: 85-120;

Hanna, Robert. 2005. Kant and nonconceptual content. European Journal of Philosophy 13: 247290 ;

Hanna, Robert. 2008. Kantian Non-conceptualism. Philosophical Studies 137: 41-64.

Harnad, Stephen, 2003. Categorical perception. In Encyclopedia of Cognitive Science, pp. 67-74. Nature Publishing Group/Macmillan.

Hattori, Masaaki, trans. 1968. Dignāga on Perception. Being the Pratyakșapariccheda of Dignāga's Pramānasamuccaya. Harvard Oriental Series 47. Cambridge, MA: Harvard University Press. 
Hattori, Masaaki. 2011. The apoha theory as referred to in the Nyāyamañjarī. In Apoha:

Buddhist Nominalism and Human Cognition, Siderits, Mark, Tom Tillemans, and Arindam Chakrabarti, eds. 134-148. New York: Columbia University Press.

Heck, Richard. 2000. Nonconceptual content and the space of reasons. Philosophical Review 109: 483-523.

Hugon, Pacale. 2011. Dharmakīrti's discussion of circularity. In Apoha: Buddhist Nominalism and Human Cognition, Siderits, Mark, Tom Tillemans, and Arindam Chakrabarti, eds. 109-124. New York: Columbia University Press.

Hurley, Susan. 1997. Non-conceptual self-consciousness and agency: perspective and access. Communication and Cognition 30 (1997): 207-248.

Katsura, Shōryū . 2011. Apoha theory as an approach to understanding human cognition. In Apoha: Buddhist Nominalism and Human Cognition, in Siderits, Mark, Tom Tillemans, and Arindam Chakrabarti, eds. 125-133. New York: Columbia University Press.

Kellner, Birgit. 2014. Changing frames in Buddhist thought: The concept of $\bar{A} k \bar{a} r a$ in Abhidharma and in Buddhist epistemological analysis. Journal of Indian Philosophy 42: 275295.

Kelly, Sean. 2001. The non-conceptual content of perceptual experience: situation dependence and fineness of grain. Philosophy and Phenomenological Research 62: 601-608.

Laurence, Stephen and Eric Margolis. 1999. Concepts and cognitive science. In Concepts: Core Readings, eds. Eric Margolis and Stephen Laurence. 3-81. Cambridge, MA: MIT Press, 1999.

Laurence, Stephen and Eric Margolis. 2012. The scope of the conceptual. In The Oxford Handbook of Philosophy of Cognitive Science, eds. Eric Margolis, Richard Samuels, and Stephen P. Stich. 291-317. Oxford: Oxford University Press. 
Lutz, Antoine, Heleen A. Slagter, John D. Dunne, and Richard J. Davidson. 2008. Attention regulation and monitoring in meditation. Trends in Cognitive Sciences 12: 163-169.

Lutz, Antoine, David R. McFarlin, David M. Perlman, Tim V. Salomons, and Richard J. Davidson. 2013. Altered anterior insula activation during anticipating and experience of painful stimuli in expert meditators. Neuroimage 64: 538-546.

Lutz, Antoine, Amishi P. Jha, John D. Dunne, and Clifford D. Saron. 2015. Investigating the phenomenological matrix of mindfulness-related practices from a neurocognitive perspective. American Psychologist 70: 632-658.

Machery, Edouard. 2009. Doing Without Concepts. New York: Oxford University Press.

Mandelbaum, Eric. 2017. Seeing and conceptualizing: Modularity and the shallow contents of perception. Philosophy and Phenomenological Research 97(2): 267-283.

Markovic, Jelena. Adam K. Anderson, and Rebecca M. Todd. 2013. Tuning to the significant: neural and genetic processes underlying affective enhancement of visual perception and memory. Behavioural Brain Research 259: 229-241.

Matthen, Mohan. 2005. Seeing, Doing, and Knowing: A Philosophical Theory of Sense Perception. New York: Oxford University Press.

Matilal, Bimal Krishna. 1986. Perception: An Essay on Classical Indian Theories of Knowledge. Oxford: Oxford University Press.

McDowell, John. 1994. Mind and World. Cambridge, MA: Harvard University Press.

McDowell, John. 2009. Avoiding the myth of the given. In John McDowell, Having the World in View: Essays on Kant, Hegel, and Sellars. 256-272. Cambridge, MA: Harvard University Press. 
McMahan, David. 2008. The Making of Buddhist Modernism. New York: Oxford University Press.

Merleau-Ponty, Maurice. 1963. The Structure of Behavior, trans. A. Fisher. Pittsburgh, PA: Duquesne University Press.

Musholt, Kristina. 2015. Thinking About Oneself: From Nonconceptual Content to the Concept of a Self. Cambridge, MA: MIT Press.

Ñāṇamoli, Bhikkhu, trans.. 1975. Visuddhimagga: The Path of Purification. Kandy, Sri Lanka: Buddhist Publication Society.

Ñāṇamoli, Bhikkhu and Bhikkhu Bodhi, trans. 1995. The Middle Length Discourses of the Buddha. A Translation of the Majjhima Nikāya. Somerville, MA: Wisdom Publications.

Noë, Alva. 2014. Concept pluralism, direct perception, and the fragility of presence. In Open MIND: 27(T) Frankfurt am Main: Mind Group. Thomas Metzinger and Jennifer Windt, eds. Doi: $10.15502 / 9783958570597$

Papies, Esther K., Lawrence W. Barsalou, and Ruud Custers. 2012. Mindful attention prevents mindless impulses. Social Psychological and Personality Science 3: 291-299.

Papies, Esther K., Tila M. Ponk, Mike Keesman, and Lawrence W. Barsalou. 2015. The benefits of simply observing: mindful attention modulates the link between motivation and behavior. Journal of Personality and Social Psychology 108: 148-170.

Patil, Parimal G. 2011. Constructing the content of awareness events. In Apoha: Buddhist Nominalism and Human Cognition, in Siderits, Mark, Tom Tillemans, and Arindam Chakrabarti, eds. 149-169. New York: Columbia University Press. 
Perlman, David M., Tim V. Solomon, Richard J. Davidson, and Antoine Lutz. 2010. Differential effects of pain intensity and unpleasantness of two meditation practices. Emotion 10 (2010): 6571.

Potter, Mary C., Brad Wyble, Carl Erik Hagmann, and Emily S. McCourt. 2014. Detecting meaning in RSVP at 13 ms per picture. Attention, Perception and Psychophysics 76: 270-279.

Potter, Mary C. and Carl Erik Hagmann. 2015. Banana or fruit? Detection and recognition across categorical levels in RSVP. Psychonomic Bulletin Review 22: 578-585.

Prinz, Jesse. 2002. Furnishing the Mind: Concepts and Their Perceptual Basis. Cambridge, MA: The MIT Press.

Pruden, Leo, trans. 1991. Abhidharmakośa Bhāṣyam by Louis de la Vallée Poussin. Volumes 1$I V$. Berkeley, CA: Asian Humanities Press.

Prueitt, Catherine. 2017. Shifting concepts: The realignment of Dharmakirti on concepts and the error of subject/object duality in Pratyabhijñā Śaiva thought. Journal of Indian Philosophy 45: 21-47.

Prueitt, Catherine. 2018. Karmic imprints, exclusion, and the creation of worlds of conventional awareness in Dharmakīrti’s thought. Sophia 57: 313-335.

Putnam, Hilary. 1981. Reason, Truth, and History. New York: Cambridge University Press.

Raffman, Diana. 1995. On the persistence of phenomenology. In Conscious Experience, Thomas Metzinger, ed. 293-308. Thorverton, UK: Imprint Academic.

Ratcliffe, Matthew. 2008. Feelings of Being: Phenomenology, Psychiatry, and the Sense of Reality. Oxford: Oxford University Press. 
Rosch, Eleanor. 1999. Reclaiming concepts. Journal of Consciousness Studies 6: 61-77.

Sen, Prabal Kumar 2011. The apoha theory of meaning: A critical account. In Apoha: Buddhist Nominalism and Human Cognition, Siderits, Mark, Tom Tillemans, and Arindam Chakrabarti, eds. 170-206. New York: Columbia University Press.

Sharf, Robert. 1995. Buddhist modernism and the rhetoric of meditative experience. Numen 42: 228-283.

Sharf, Robert. 2015. Is mindfulness Buddhist? (And why it matters). Transcultural Psychiatry 52: $470-484$.

Sharf, Robert. 2018. Knowing blue: Early Buddhist accounts of non-conceptual sense perception. Philosophy East and West 68(3): 826-870.

Siderits, Mark. 2007. Buddhism as Philosophy. Surrey, UK: Ashgate Publishing Company and Indianapolis, IN: Hackett Publishing Company.

Siderits, Mark. 2015. Personal Identity and Buddhist Philosophy: Empty Persons. Ashgate Publishing.

Siderits, Mark. 2016. Studies in Buddhist Philosophy. New York: Oxford University Press.

Siderits, Mark, Tom Tillemans, and Arindam Chakrabarti, eds. 2011. Apoha: Buddhist Nominalism and Human Cognition. New York: Columbia University Press.

Slingerland, Edward. 2003. Effortless Action: Wu-Wei as Conceptual Metaphor and Spiritual Ideal in Early China New York: Oxford University Press.

Slingerland, Edward. 2014. Trying Not to Try: The Art and Science of Spontaneity New York: Crown. 
Strawson, P. F. 1999. Reply to Arindam Chakrabarti. In The Philosophy of P.F. Strawson, ed. Lewis Edwin Hahn. 324-328. Chicago and LaSalle, IL: Open Court Publishing.

Taber, John. 2005. A Hindu Critique of Buddhist Epistemology: Kumārila on Perception. The “Determination of Perception” chapter of Kumārila Bhaț̣’s Ślokavārttika. London and New York: Routledge Press.

Thompson, Evan. 1991. Is internal realism a philosophy of scheme and content? Metaphilosophy 22: 212-230.

Thompson, Evan. 1995. Colour Vision: A Study in Cognitive Science and the Philosophy of Perception. London: Routledge Press.

Thompson, Evan. 2007. Mind in Life: Biology, Phenomenology, and the Sciences of Mind. Cambridge, MA: Harvard University Press.

Thompson, Evan. 2015. Waking, Dreaming, Being: Self and Consciousness in Neuroscience, Meditation, and Philosophy. New York: Columbia University Press.

Thurman, Robert. trans. 1976. The Holy Teaching of Vimalakīrti: A Mahāyāna Scripture. University Park and London: Pennsylvania State University Press.

Tillemans, Tom J. F. 1997. Dharmakīrti on prasiddha and yogyatā. In Aspects of Buddhism: Proceedings of the International Seminar on Buddhist Studies, eds. Agata Bareja-Starzyńska and Marek Mejor 161-176. Warszawa, Poland: Instytut Orientalistyczny.

Tillemans, Tom. 2011. How to talk about ineffable things: Dignāga and Dharmakīrti on apoha. In Apoha: Buddhist Nominalism and Human Cognition, in Siderits, Mark, Tom Tillemans, and Arindam Chakrabarti, eds. 50-63. New York: Columbia University Press. 
Tillemans, Tom. 2017. Dharmakīti. The Stanford Encyclopedia of Philosophy (Spring 2017 Edition), Edward N. Zalta (ed.), URL = https://plato.stanford.edu/archives/spr2017/entries/dharmakiirti/, Section 1.2.

Todd, Rebecca M., William A. Cunningham, Adam K. Anderson, and Evan Thompson. 2012. Affect-biased attention as emotion regulation. Trends in Cognitive Sciences 7: 365-372.

Tzohar, Roy. 2016. Enjoy the silence: The relation Between non-conceptual awareness and inexpressibility according to some Yogācāra sources. Paper presented at the workshop, "Conceptuality and Nonconceptuality in Buddhist Thought," University of California, Berkeley, Center for Buddhist Studies, November 4-6, 2016.

Urban, Hugh B. and Paul J. Griffiths. 1994. What else remains in śūnyatā? An investigation of terms for mental imagery in the Madhyāntavibhäga-Corpus. Journal of the International Association of Buddhist Studies 17(1): 1-25.

Varela, Franciso J., Evan Thompson, and Eleanor Rosch. 1991/2017. The Embodied Mind: Cognitive Science and Human Experience. Cambridge, MA: MIT Press.

von Rospatt, Alexander. 1995. The Buddhist Doctrine of Momentariness: A Survey of the Origins and Early Phase of this Doctrine Up to Vasubandhu. Stuttgart: Steiner.

Wayman, Alex. 1992. Buddhist terms for recollection and other types of memory. In In the Mirror of Memory: Reflections on Mindfulness and Remembrance in Indian and Tibetan Buddhism, ed. Janet Gyatso. 133-147. Albany, NY: State University of New York Press.

Wittgenstein, Ludwig. 1958. Philosophical Investigations, trans. G. E. M. Anscombe. Oxford: Basil Blackwell.

Zahavi, Dan. 2005. Subjectivity and Selfhood: Investigating the First-Person Perspective. Cambridge, MA: MIT Press. 
Zeidan, Fadel, Katherine T. Martucci, Robert A. Kraft, Nakia S. Gordon, John G. McHaffie, and Robert C. Coghill. 2011. Brain mechanisms supporting the modulation of pain by mindfulness meditation. Journal of Neuroscience 31: 5540-5548. 